\title{
Panacea, Curse, or Nonevent? \\ Unconventional Monetary Policy in the \\ United Kingdom
}

André Meier 


\title{
IMF Working Paper
}

European Department

\section{Panacea, Curse, or Nonevent? Unconventional Monetary Policy in the United Kingdom}

Prepared by André Meier*

Authorized for distribution by Peter Doyle

August 2009

\begin{abstract}
This Working Paper should not be reported as representing the views of the IMF. The views expressed in this Working Paper are those of the author(s) and do not necessarily represent those of the IMF or IMF policy. Working Papers describe research in progress by the author(s) and are published to elicit comments and to further debate.
\end{abstract}

The Bank of England's current "quantitative easing" strategy has given rise to a controversial debate about the effects and risks of unconventional monetary policy. The present paper makes two contributions to this debate. First, it provides a systematic overview of unconventional policy options, drawing from existing theoretical and empirical studies. Against this backdrop, it then analyzes the BoE's specific policies, discussing their effectiveness so far and putting them into a cross-country context. Tentative evidence on the BoE's quantitative easing is moderately encouraging, although the strategy is neither guaranteed to succeed nor as perilous as some of its detractors claim.

JEL Classification Numbers: E41, E43, E51, E52, E58

Keywords: Unconventional monetary policy; liquidity trap; zero bound; quantitative easing Author's E-Mail Address:ameier@imf.org

\footnotetext{
* I would like to thank Ajai Chopra, Martin Cihak, Sergei Dodzin, Peter Doyle, Marcello Estevao, Kenji Fujita, Dora Iakova, Kotaro Ishi, Vladimir Klyuev, Charles Kramer, Koshy Mathai, Murtaza Syed, Man-Keung Tang, Erica Tsounta, and seminar participants at the Bank of England for very helpful suggestions. All errors are my own.
} 


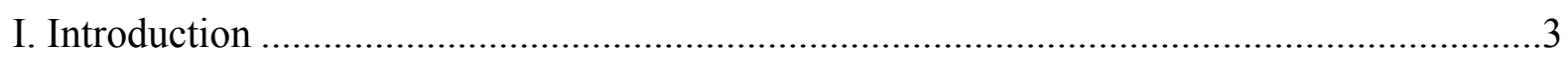

II. Rationale for Unconventional Monetary Policy .....................................................

III. Scope for Unconventional Operations ..................................................................6

A. Theoretical Benchmark: Skepticism about Effectiveness................................... 8

B. Two General Objections to the Skeptics' View ................................................. 8

IV. Specific Policy Options ............................................................................................ 10

A. Announcement to Keep Short-Term Rates Low for an Extended Period...............10

B. Fixed-rate Refinancing Operations with Extended Maturity ................................11

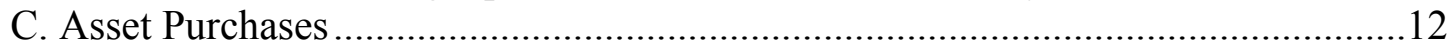

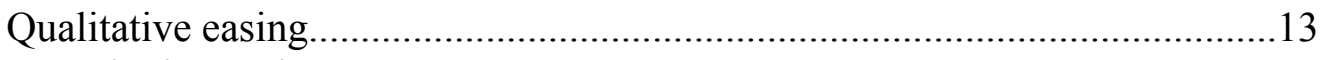

Quantitative easing........................................................................ 15

V. Risks and Mitigation Strategies ............................................................................. 18

A. Uncertainty About the Right Dosage, Timing, and Exit...................................18

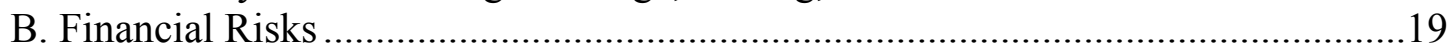

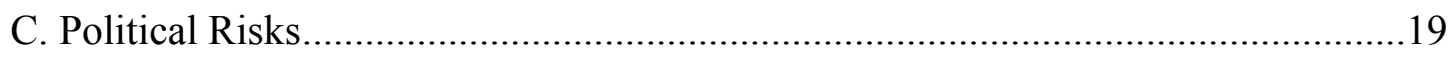

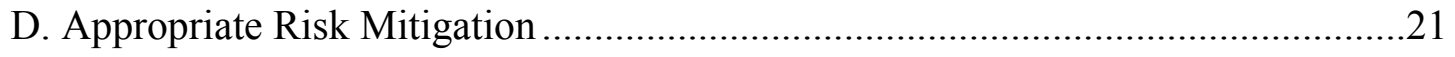

VI. Unconventional Monetary Policy in the United Kingdom .........................................22

VII. Gauging the Effectiveness of Unconventional Policies ..........................................26

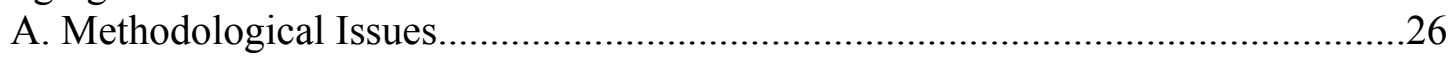

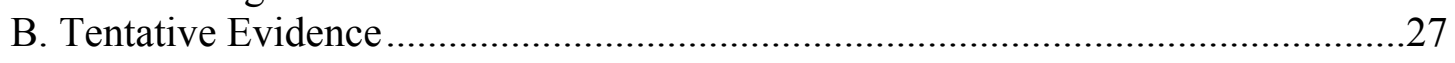

VIII. Comparison with Other Advanced Country Central Banks.........................................34

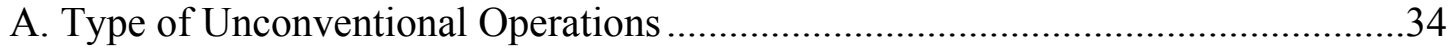

Communication about future policy rates.................................................34

Longer-term fixed-rate refinancing operations ..........................................36

Asset purchases ...............................................................................36

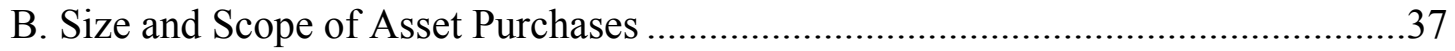

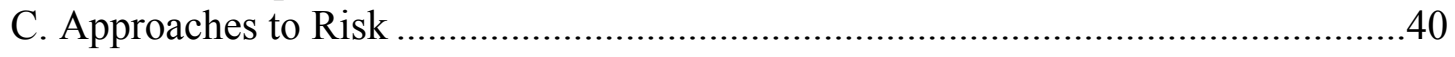

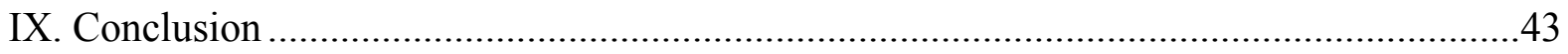

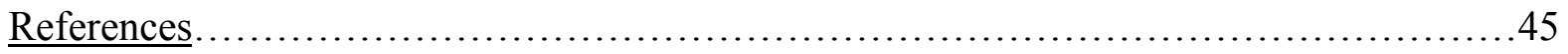

Figure 1: $\quad$ Interest Rates and Central Bank Balance Sheets, 2008-09 ....................4

Box 1: $\quad$ Do Explicit Asset Price Targets Provide a Foolproof Solution? ..................17 


\section{INTRODUCTION}

The global financial crisis has given risen to strong disinflationary dynamics, associated with stretched private balance sheets, weak asset prices, fragile banks, and faltering demand. Inflation rates have eased from their mid-2008 peaks in all advanced economies and are now in many cases below the relevant targets. The outlook is unusually uncertain, depending on the extent of further deleveraging and the shape of the economic recovery. Yet it is clear that averting a sustained inflation undershooting has moved to the top of central banks' agendas.

The challenge facing central banks is heightened by the effect of the financial crisis on monetary transmission. While some standard channels, such as the exchange rate channel, remain intact, the usual interest rate and bank lending channels have arguably been impaired by the widespread dislocations in credit markets. Risk premia have surged, lending standards have been tightened, and in some cases entire credit markets have effectively shut down. Accordingly, financing conditions are tighter than low policy rates alone would suggest.

This constellation has revived interest in unconventional monetary policy options. In fact, within a matter of months, central banks in many advanced economies have cut policy rates to the lower bound and put in place unconventional monetary operations, often alongside unprecedented action to restore financial stability (Figure 1). As a result, central banking has been anything but what its protagonists would like it to be, i.e., "boring" (King, 2000).

The adoption of unconventional monetary policies, notably the credit easing and quantitative easing strategies implemented by the U.S. Federal Reserve (Fed) and the Bank of England (BoE), has given rise to a rich public debate. Opinions span a wide range, with Congdon (2009) calling the BoE's policy "almost an unqualified success", while Halligan (2009) decries the prospect of currency debasement and high inflation, and Buiter (2009) declares quantitative easing "a yawn". This variety of views - panacea, curse, or nonevent-reflects significant disagreement on the way unconventional monetary policy operates.

Against this backdrop, the present paper provides a systematic discussion of the BoE's recent policy choices. The first part of the paper deals with unconventional monetary in general. The exposition is kept relatively nontechnical and chiefly aims to synthesize existing research. The second part, which is sufficiently self-contained to be read separately, details the BoE's policy actions and evaluates them in light of the preceding general discussion. The analysis focuses on tentative indications of the policies' effectiveness and compares their scale, scope, and riskiness to the strategies pursued by other advanced country central banks. Given this focus, the paper avoids a detailed discussion of the UK inflation outlook-an important but separate topic. Rather, it starts from the assessment in IMF (2009) that the current juncture warrants greater monetary stimulus than low policy rates alone can deliver. 
Figure 1. Interest Rates and Central Bank Balance Sheets, 2008-09

Policy and Interbank Market Rates (Percent)
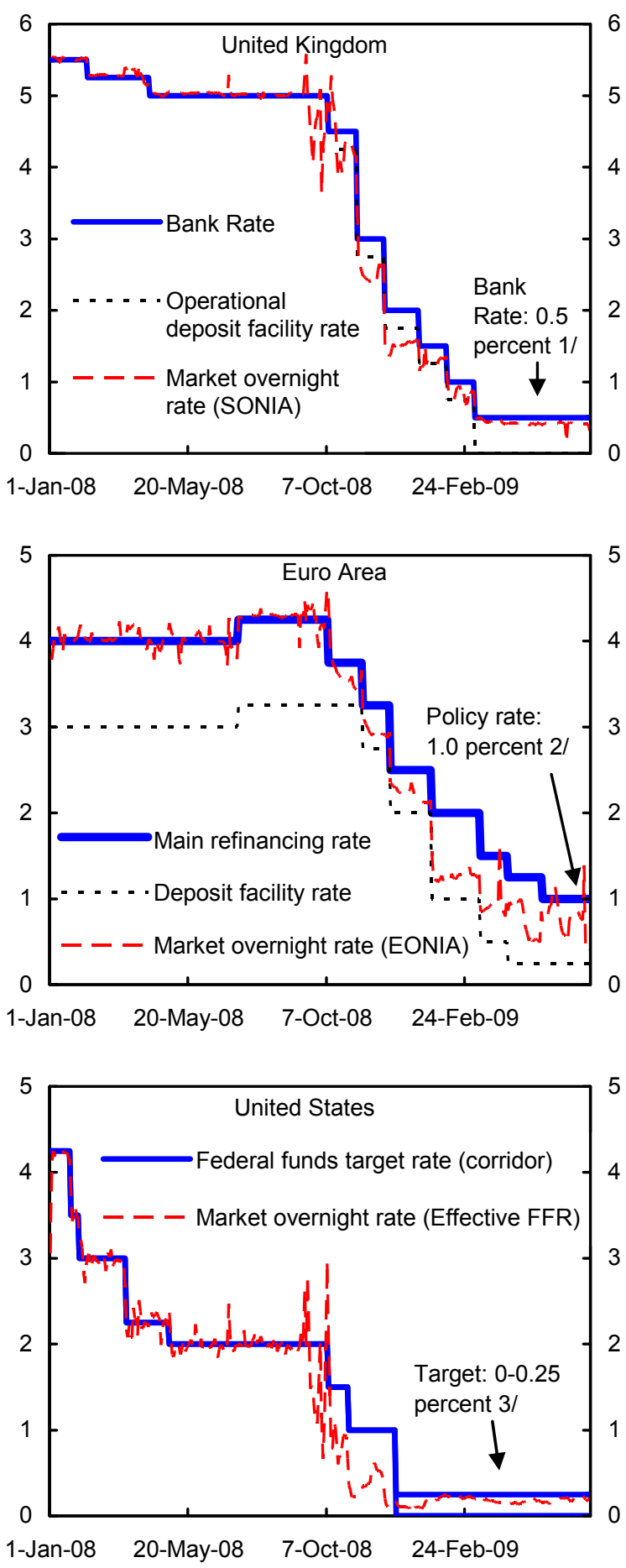

Central Bank Liabilities (Billions of national currency)
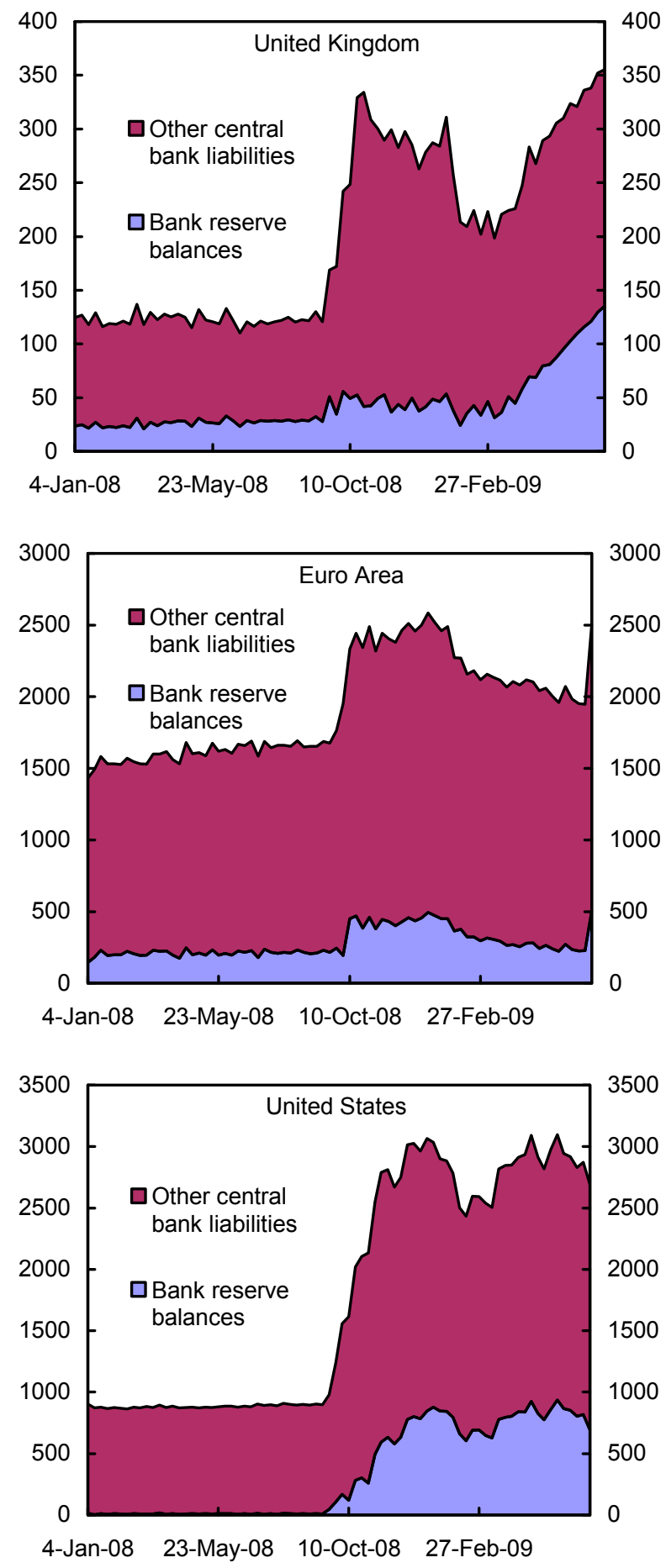

Sources: Haver Analytics; and IMF staff calculations.

$1 /$ All reserves of banks participating in reserve scheme currently remunerated at 0.5 percent; deposit rate at 0 percent.

2/ Minimum reserves remunerated at 1.0 percent; excess reserves unremunerated; deposit rate: 0.25 percent.

3 / All reserves currently remunerated at 0.25 percent. 
The remainder of this paper is structured as follows: Section II sketches the rationale for unconventional monetary operations. This is followed, in Section III, by a brief general discussion on the scope for such operations to affect economic outcomes. Section IV analyzes specific tools in detail, before Section V turns to risks and mitigation strategies. Section VI zooms in on the current UK experience, describing the BoE's unconventional policies. In order to gauge their effectiveness, Section VII outlines a set of straightforward empirical approaches and discusses the findings. Section VIII broadens the perspective by comparing the BoE's policies to those of other advanced country central banks and highlighting the apparent policy trade-offs. Section IX provides a summary and concludes. ${ }^{1}$

\section{Rationale for UnConventional Monetary Policy}

The key purpose of monetary policy is to preserve price stability. In several advanced economies, this objective is institutionalized in formal inflation targeting regimes. The BoE's mandate to keep CPI inflation close to a 2-percent target is one example. Some other major central banks do not explicitly conduct inflation targeting, but achieving low inflation is nonetheless their overriding goal (European Central Bank) or one central objective (Fed).

The conventional tool of monetary policy today is control over short-term nominal interest rates. Despite variation in the specific setup of monetary operations, all major central banks set policy by targeting some short-term interbank rate, usually for overnight funds ("policy rate"). In most cases, this is implemented by announcing a target rate and conducting appropriate open market operations so as to keep interbank rates in line with this target. ${ }^{2}$ Liquidity-providing operations normally take the form of reverse transactions against a menu of eligible collateral that is meant to minimize risks to the central bank's balance sheet. By steering the level of money market interest rates, the central bank effectively relies on the financial system's distribution function to transmit the monetary stance into broader financing conditions facing the real sector.

However, policy rates are bounded from below at or near the zero floor, limiting the extent of monetary stimulus that can be provided through rate cuts alone. Discussion of this problem has a long tradition in macroeconomics, with key contributions going back to Keynes (1936). Essentially, at zero interest rates, holding cash becomes a serious alternative to keeping bank

\footnotetext{
${ }^{1}$ The data cutoff point for the analysis in this paper is June 30, 2009.

${ }^{2}$ A special situation has recently arisen in some cases as a result of massive liquidity provision to banks. If the central bank does not "mop up" excess reserves at the policy rate (e.g., 1 percent at the ECB), money market rates tend to fall toward the floor imposed by deposit facilities $(0.25$ percent at the ECB). However, since excess liquidity only drives a wedge between market and policy rates if the central bank allows it to, this situation is best thought of as a deliberate lowering of the effective policy rate. As such, extended liquidity provision to banks through otherwise standard facilities is not discussed as an unconventional tool below.
} 
deposits. Even if cash holdings are associated with some storage, insurance, or other transaction costs, these are low enough to rule out significantly negative interest rates. In practice, central banks may actually accept a strictly positive lower bound. Reasons for avoiding zero policy rates include, notably, concerns about the resulting breakdown of money market activity, as participants would lose any incentive to trade among themselves.

Yet even a zero policy rate may still be too high to stimulate an economy gripped by strong deflationary forces. This problem was made very explicit by a recent Fed staff assessment whereby the right policy rate would be minus 5 percent (reported in Financial Times, 2009). As targeting such a rate is not feasible, central banks have turned to alternative operations.

A switch to unconventional policy has also been motivated by the severe turmoil in credit markets. With the financial sector in crisis, policy rate cuts are not only constrained by the zero bound, but may also be less effective than during normal times. The reason is the sharp tightening of credit conditions, as lenders have curtailed loan supply and certain sources of capital market funding have all but disappeared. Indeed, such dislocations can provide a rationale for launching unconventional policies even before interest rates hit the lower bound.

In sum, unconventional monetary policies serve both as a complement and as an extension of standard operations centered around the setting of short-term interest rates.

\section{SCOPE FOR UNCONVENTIONAL OPERATIONS}

Discussing unconventional operations not only requires a definition of what is conventional, but also some restrictions on the realm of the unconventional. After all, it would not be reasonable to cover the entire range of functions usually assigned to the fiscal authority or the private sector, such as large-scale public procurement or long-term lending to households. In order to limit the discussion to practically relevant "monetary policy" at least in a broad sense of the term, we focus here on unconventional policy options that are currently under consideration or implementation by advanced country central banks. Specifically, we consider explicit communication on future policy rates, refinancing operations at extended maturities, and asset purchases, with or without base money expansion. This list also matches the menu of options discussed in earlier academic work, including Clouse et al. (2000), Blinder (2000), and Bernanke and Reinhart (2004).

Consequently, the discussion will not cover options that represent interesting theoretical concepts without much chance of practical implementation. This includes, notably, the suggestion to engineer negative short-term market interest rates, e.g., by imposing a tax on cash holdings and deposits, as originally proposed by Gesell (1934), and more recently by Buiter and Panigirtzoglou (1999) and Goodfriend (2000). Even leaving aside questions of 
technical feasibility, political resistance to such proposals and possibly large adverse confidence effects are all but certain to rule out negative effective policy rates. ${ }^{3}$

Given the intended focus on alternative monetary operations, we will also abstract from explicit changes to policy targets. The question of this paper, after all, is how unconventional policy tools can help to achieve a given target. This is not to deny, however, that the zero bound problem may be relevant for the design of optimal policy targets. In particular, the risk of running out of standard policy ammunition at the zero bound has prompted several authors to argue either for a sufficiently high inflation target (e.g., Summers, 1991) or for a switch to price level targeting (e.g., Svensson, 2001). Under the latter, the central bank would aim to keep the price level close to a preset target path, effectively promising to make up for past temporary inflation over/undershooting with below/above-average inflation in the future. ${ }^{4}$

Moreover, we will abstract from central bank action that is driven primarily by concerns about financial stability, as opposed to monetary policy. To be sure, the two are interlinked, as the breakdown of the banking system also has implications for monetary transmission and inflation outcomes. Still, central bank schemes for liquidity insurance and lender-of-lastresort facilities clearly relate to distinct financial stability mandates that deserve discussion as a separate topic. To give an example, emergency liquidity provision to banks in response to a run (like the wholesale market run suffered after the Lehman collapse in September 2008) is not originally aimed at stimulating aggregate demand, but instead serves to preserve the very banking system on which the central bank relies for its standard monetary operations.

Similarly, central banks' decision to relax collateral requirements for repurchase operations is generally not meant to provide targeted stimulus, but reflects an attempt to keep the conventional policy framework - secured short-term lending to banks at the policy rateoperative even as banks run out of standard collateral. Despite this difference in intent, the effects of financial stability interventions are sometimes similar to those sought by unconventional monetary policy. For instance, acceptance of certain private securities as collateral can reduce liquidity premia, much like the unconventional monetary tool of outright security purchases.

\footnotetext{
${ }^{3}$ While remarkable, the Swedish central bank's July 2 decision to lower the rate on its standing deposit facility to -0.25 percent is consistent with this assessment. Under the Swedish monetary framework, daily fine-tuning operations are employed to keep the overnight interbank market rate within 10 basis points of the repo rate, i.e., the Riskbank's policy rate, which is currently at its declared floor of 0.25 percent and thus still firmly in positive territory. The deposit facility, in turn, serves only as a backstop in case of unforeseen fluctuations (or liquidity management errors in individual banks) and, accordingly, tends to be used in minimal amounts.

${ }^{4}$ Price-level targeting has appealing theoretical properties insofar as it provides a very reliable basis for longterm nominal contracting. However, it also faces credibility challenges, as its inherently backward-looking nature may appear very costly at times. This is the case, in particular, when a past inflation surge requires the central bank not only to reduce inflation to the desired average, but even to engineer a temporary undershooting of that rate. In practice, no central bank conducts price-level targeting today.
} 


\section{A. Theoretical Benchmark: Skepticism about Effectiveness}

With interest rates assumed to be at the lower bound, how much scope is there for unconventional monetary policy to provide additional stimulus to the economy? The answer provided by benchmark macroeconomic models is largely negative. The standard New Keynesian models presented by Eggertsson and Woodford (2003) and Eggertsson (2006), for example, imply that the impact of monetary policy on the real economy is fully described by the current policy rate and the expected path of future policy rates. Unless unconventional measures change the public's expectations about the future path of policy, there is no channel to influence economic activity at the lower bound for interest rates. This prediction is the modern-day (i.e., microfounded dynamic general equilibrium) refinement of the famous "liquidity trap", whereby further monetary expansion at the lower bound provides no stimulus as agents' demand for money balances becomes infinitely elastic.

The basic ineffectiveness of unconventional monetary operations in standard modern macroeconomic models can be traced to two key assumptions, i.e., frictionless financial markets and a "super-robust" inflation targeting framework. First, asset prices in Eggertsson and Woodford (2003) depend only on the asset's state- and time-contingent payoffs, ruling out phenomena like quantitative credit restrictions or, indeed, any impact of asset supplies on risk premia. In essence, this reproduces the perfectly elastic asset demand curves of even simpler models in which yields are pinned down by expectations of future short-term rates and a fixed risk premium - the well-known expectations hypothesis. Second, standard models routinely describe central bank action by a simple (welfare-maximizing) policy rule. At the zero bound for interest rates, it would be ex ante optimal to announce that rates will be kept low long enough to engineer some temporarily higher inflation in the future-a policy Krugman (1998) describes as "committing to being irresponsible". Such a policy would raise inflation expectations and thus reduce real interest rates today, providing extra stimulus. However, delivering on this commitment is no longer socially optimal once the economy escapes from the liquidity trap, as the central bank would want to prevent any overshooting of the inflation target at that time. Agents understand the central bank's optimization problem and rationally expect it to choose the best policy at any point in time. Accordingly, pledges of "irresponsible" future policymaking are not credible in the absence of an explicit commitment mechanism. This time inconsistency problem, which ironically arises from the "super-credibility" of the central bank's inflation targeting mandate, constrains the room for providing monetary stimulus at the zero bound.

\section{B. Two General Objections to the Skeptics' View}

The theoretical argument stated by Eggertsson (2006) represents an important reference point, as it clarifies that at least one of the usual textbook assumptions must be relaxed to create scope for unconventional policy to become effective. In fact, there are good reasons to think that both of the assumptions discussed above are somewhat too restrictive. 
First, the dynamics of financial markets and risk premia are likely to be richer than captured in a frictionless complete-markets model. To be sure, the standard expectations hypothesis remains a very relevant benchmark, especially since alternatives are rather difficult to model. ${ }^{5}$ However, it certainly appears conceivable that actual demand curves for assets are downward-sloping, so that changes in asset supply can affect risk premia or, in the case of "supply overhang", even lead to a complete shutdown of market activity. The underlying frictions may be negligible in most financial markets in normal times, but they arguably become more relevant during times of crisis, precisely when unconventional monetary policy enters the scene. Indeed, the mere fact that there is a very large number of assets with nontrivial risk premia indicates the limitations of the most basic liquidity trap scenario: a zero interest rate on short-term government bonds may constrain the effects of monetary expansion, but it is very unlikely to be the only market price that is relevant for money demand. As long as other market rates remain above the lower bound, there may thus be some room for affecting aggregate demand through changes in these other rates.

Second, the above-mentioned assumption about the central bank's optimization problem probably overstates the robustness of actual policy frameworks, or at least agents' perception thereof. In particular, it seems hard to believe that very aggressive monetary easing today would do nothing at all to affect agents' anticipation of future policies. ${ }^{6}$ Even where monetary policy is delegated to an independent central bank, it ultimately hinges on the broader political support for low inflation. This support, in turn, may be weaker than the standard model posits, for example, because of existing large debt stocks. Yet, this argument cuts both ways. If indeed agents' expectations about future policy are less firmly anchored than the standard model assumes, conservative central banks may be wary of very aggressive easing to begin with, lest inflation expectations could "overreact" and become unhinged.

Hence, unconventional monetary policy can be effective to the extent that (i) it convinces the public of a looser-than-expected future policy stance (relative to inflation developments) or (ii) it directly reduces risk premia or outright quantitative restrictions in financial markets. With these general considerations in mind, we now turn to specific policy options.

\footnotetext{
${ }^{5}$ One notable attempt is the paper by Andres, Lopez-Salido, and Nelson (2004), which introduces time-varying, stochastic transaction costs in the bond market as a way to model the illiquidity of long-term bonds. It also assumes that households holding long-term bonds compensate for their illiquidity by holding more currency, as a self-imposed "reserve requirement" of sorts. Lastly, the model features heterogeneous agents, some of which only trade long-term bonds. Together, these assumptions give rise to deviations from the expectations theory of the term structure, generating asset supply effects on bond spreads and aggregate demand.

${ }^{6}$ In fact, Eggertsson and Woodford (2004) allow for this possibility to the extent that a sharp monetary easing today contains a credible signal about future policy intentions. The signal could be made credible, in particular, by unconventional operations that affect the policymaker's future optimization problem. In this vein, Eggertsson (2006) and Jeanne and Svensson (2007) argue that central bank purchases of real or foreigncurrency assets, along with higher domestic public debt, can incentivize policymakers to accept higher future inflation, as this would imply capital gains and/or a reduced need for distortionary taxation to pay down debt.
} 


\section{SPECIFIC Policy Options}

\section{A. Announcement to Keep Short-Term Rates Low for an Extended Period}

Expectations of future policy rates can have immediate effects above and beyond the current rate, via their impact on longer-term yields. This gives a role to central bank communications even in normal times. With short-term rates at the lower bound, the communication channel gains even greater prominence. Krugman (1998) and Orphanides and Wieland (2000), for instance, have suggested that central banks should commit to keeping policy rates down for an extended period. If it is unexpected, the central bank's commitment should immediately lower longer-term bond rates, support other asset prices, and boost demand.

However, the announcement must be credible to affect expectations. Under discretionary policymaking, this implies that the central bank's communications must be consistent with private sector perceptions of its objectives and outlook for the economy. Two cases can be distinguished in this regard. First, if the market does not properly assess the central bank's "standard" policy reaction function, a clarifying announcement could possibly convey new information. In practice, the room for correcting such market misperceptions is likely to be limited for central banks with a clear mandate and an established track record. In particular, a conditional announcement to keep rates low until inflation returns toward the target may simply be restating the well-known essence of an inflation targeting framework.

By contrast, the central bank could signal an effective departure from its usual policy reaction function, notably by making unconditional statements about near-term policy or by conditioning an exit from its loose policy on more than just a moderate return of inflation. Inflation targeting regimes usually give some flexibility —in terms of the time horizon over which inflation would return to the target - to signal such intent, but within bounds. Specifically, central bankers will be hesitant to announce significant departures from normal practice, as this would likely weaken the credibility of either the existing framework or the central bank's announcements. Indeed, purely forward-looking statements generally risk being perceived as cheap talk, unless backed by concrete policy action as discussed below.

Even so, there is some empirical evidence for the effectiveness of central bank "talk". Bernanke, Reinhart, and Sack (2004) consider the case of the Fed's communications policy. Using an event study analysis as well as an arbitrage-free term structure model, they find that the Fed's statements have had a significant impact on market expectations of future policy rates, above and beyond the effect of current interest rate changes. Japan's zero interest rate policy (ZIRP), which started in February 1999 and then again in March 2001, provides another testing ground, but the results are more mixed here. In line with earlier studies, Bernanke, Reinhart, and Sack (2004) do not find a significant impact of Bank of Japan (BoJ) communications on one-year ahead expectations. However, ZIRP appears to have had some effect on the shape of the yield curve. 


\section{B. Fixed-rate Refinancing Operations with Extended Maturity}

Rather than trying to "talk down" term interest rates in the interbank market, the central bank could directly extend its monetary easing along the yield curve by providing banks with fixed-rate funding at longer-than-usual maturities. Banks' demand for such funding should be a function of expected future policy rates and the uncertainty around these expectations, as expressed in term premia. One approach for the central bank is to maintain a price auction and provide a fixed amount of longer-term funding at whatever interest rate is offered by banks. As the amount grows, such liquidity provision is likely to ease term premia. In fact, the central bank can expand its longer-term operations well beyond the overall liquidity needs of the banking system provided that it either accepts the resulting pressure on shortterm market rates (an effective policy rate cut) or it has tools in place to impose the desired lower bound, for example, through a deposit facility. In this case, it would be lending to banks at the longer end of the money market curve and re-borrowing at the short end.

An even more powerful way to lower the interbank market yield curve is to make longerterm funds available at a preset rate below current market levels. Assuming that the central bank stands ready to provide any amount (against collateral) demanded at this rate, it effectively imposes a ceiling on all market rates up to that horizon. The extent of banks' demand for such funding will depend on the credibility of the signal sent by the central bank's unconventional operation. If banks are convinced that the central bank will keep its short-term policy rate at the lower bound over the entire horizon of the longer-term operation, these operations may not have to involve very significant amounts. If, however, the market continues to doubt the central bank's low-rate commitment, very large amounts might be demanded in what becomes effectively a one-way bet against the central bank's resolve. At the limit, the central bank might be saddled with huge, relatively long-term claims against the banking system. In case it reneges on its rate commitment later on, it could suffer correspondingly large losses, i.e., by paying higher interest rates on its short-term reborrowing from banks than it earns on its longer-term lending. The risk of this happening may, on the one hand, make the low-rate pledge more credible. ${ }^{7}$ On the other hand, in keeping with a now-familiar pattern of trade-offs, it may also make the central bank more wary of conducting such longer-term operations in the first place. This concern seems especially relevant as policymakers can never quite rule out unforeseen developments that would make it prudent to deviate from the anticipated policy rate path in the future.

These challenges obviously become greater the longer the maturity of preset-rate refinancing operations. Indeed, even supporters of this particular tool, like Orphanides (2004), caution that it is arguably not practical to extend it to truly long-term horizons. ${ }^{8}$ Moreover, the

\footnotetext{
${ }^{7}$ Clouse et al. (2004) discuss a similar mechanism involving the sale of financial options by the central bank. Specifically, the central bank would write options that protect counterparts against future interest rate increases.

${ }^{8}$ The possible targeting of long-term rates, for example on government bonds, is discussed in Box 1.
} 
obvious interaction between rates at different maturities makes it necessary to develop an appropriate exit strategy for the longer-term operations, such as a phasing-out or increase in the longer-term interest rate well before short-term rates are expected to rise.

\section{Asset Purchases}

The operations discussed so far retain a conventional element in that they remain focused on interest rates in the interbank market. This subsection, instead, deals with a broad class of operations that use the central bank's balance sheet in order to affect directly a broader set of market rates, asset prices, and even lending amounts. As such, they represent an attempt to short-circuit and/or enhance the usual transmission from money market rates into financial conditions facing the wider economy.

Within the broad category of asset purchases, we distinguish operations by their impact on, respectively, the asset and liability sides of the central bank balance sheet. Operations that expand the monetary base (beyond the quantity needed to maintain the current policy rate) are commonly referred to as "quantitative easing"; those that change the composition of central bank assets without affecting base money could be referred to as "qualitative easing", following Buiter (2008). On the asset side, in turn, the recent policy debate has established the term "credit easing" for operations targeting private (domestic) credit markets. The emphasis of these operations is on security purchases or even direct lending in order to enhance market liquidity, reduce risk spreads, promote new issuance, and increase private access to credit. By contrast, purchases of domestic government bonds will generally aim, at least as a first-round effect, for a flattening of the benchmark yield curve. Lastly, purchases of foreign-currency denominated assets are frequently meant to provide stimulus through a depreciated exchange rate, thus completing the basic menu of options (text table).

Schematic Overview of Unconventional Monetary Policy Operations Involving Asset Purchases

\begin{tabular}{|c|c|c|c|}
\hline & & \multicolumn{2}{|c|}{ Liability Side of the Central Bank Balance Sheet } \\
\hline & & $\begin{array}{l}\text { No expansion of base money } \\
\text { (= "Qualitative easing") }\end{array}$ & $\begin{array}{l}\text { Expansion of base money } \\
\text { (= "Quantitative easing") }\end{array}$ \\
\hline \multirow{3}{*}{$\begin{array}{c}\text { Asset Side: } \\
\text { Purchases } \\
\text { of... }\end{array}$} & Government bonds & "Flattening" of yield curve & Pure quantitative easing \\
\hline & Private domestic-currency assets & Credit easing & Credit easing \\
\hline & Foreign-currency assets & "Sterilized" intervention & "Unsterilized" intervention \\
\hline
\end{tabular}




\section{Qualitative easing}

Qualitative easing involves sterilized purchases of assets whose valuation or availability the central bank would like to affect. Traded securities represent the most obvious application, but we use the term here in a wider sense that also covers direct lending to nonbanks. The purchases can be financed in different ways, notably by (i) selling or lending out existing central bank assets, usually (short-term) government paper; (ii) issuing nonmonetary liabilities where available (for example, BoE sterling bills); or (iii) obtaining agreement from the fiscal authority to issue new short-term government paper and deposit the proceeds with the central bank. As the money supply is unaffected by such operations, they are readily implemented at interest rates above the lower bound.

One key channel for qualitative easing to be effective is the rebalancing of private portfolios. Portfolio rebalancing can induce the desired price effects if market valuations are responsive to changes in asset supply, i.e., if higher/lower current holdings of a risky asset make investors less/more accepting of an additional unit of the same risk. This requires that the relevant assets be imperfect substitutes for each other. Consider the case in which central bank purchases reduce the share of asset A in private portfolios. If asset A cannot be perfectly substituted with the asset sold by the central bank, investors will try to rebalance their portfolios to increase again the share of asset A (or sufficiently close substitutes). As the overall supply has declined, this rebalancing effort will bid up the price of asset A. Accordingly, qualitative easing is likely to be more effective the greater the dissimilarity between the asset purchased and the asset sold (usually short-term government paper).

Importantly, portfolio rebalancing relies on affecting private investors' valuation of the asset, not just driving up prices for as long as central bank purchases continue. To clarify this point, note that the central bank could maintain any arbitrarily high floor for the price of a particular asset provided it can sell enough other assets to finance its purchases. Yet private valuations are unlikely to settle at the central bank offer price while there are at least some cheaper, close-enough substitutes for the asset in question. Hence, the central bank may well end up owning the entire stock of the asset without achieving the desired effect on market prices. Indeed, its purchases would mainly subsidize current asset owners - a purely fiscal operation. Similarly, a notable impact on private valuations is unlikely if the central bank purchases are expected to be fully reversed in the near future. This recalls the general theme that the central bank's virtue, i.e., its readiness to quickly unwind stimulus once economic conditions improve, may be its vice when it comes to unconventional policies.

The scope for portfolio balance effects is controversial. As noted in the preceding section, such effects are absent from standard modern models of the macroeconomy. At the same time, the idea of imperfect asset substitution has a long tradition in macroeconomics, as exemplified by Tobin (1969). Relevant empirical studies are limited and usually focus on a few selected markets. Sterilized currency intervention, in particular, has received significant 
interest, but evidence on its effectiveness is mixed (Sarno and Taylor 2002, pp. 221-26). Bernanke, Reinhart, and Sack (2004) examine a few other "experiments", including the surprise announcement of U.S. treasury buybacks in the early 2000s and the large-scale purchases of U.S. treasuries by the Japanese authorities a few years later. In both cases, the purchases are estimated to have caused changes in yields of some 50 basis points. That said, the authors' findings also suggest a risk of rate "decoupling". Specifically, the buyback of 30 -year treasuries appears to have had only very modest spill-over effects into private interest rates. Taken together, these results suggest some scope for portfolio balance effects, although their extent may be limited in large and liquid asset markets.

In fact, the most compelling case for direct pricing effects exists in asset markets that have become illiquid and dysfunctional. Disruptions in financial intermediation, for instance, may reduce the number of market participants, diminish liquidity, and limit arbitraging. In even more extreme cases, market activity may shut down altogether. Under such conditions, welltargeted official operations may actually correct, rather than create market distortions. A similar theoretical argument can also be made for the case where market valuations reflect worst-case assumptions in a situation of multiple equilibria. Official intervention in this case could help bring asset prices in line with a superior equilibrium, thus providing a form of virtuous coordination. Needless to say, the existence of such conditions will seldom be easy to ascertain in practice. Hence, targeted asset purchases are exposed to the same criticism as the notion that policymakers can identify (and try to counteract) asset price bubbles. This concern will be of particular relevance when the central bank not only buys assets in an existing marketplace but actually "reopens" a market, for example, by offering fixed-rate loans that have otherwise become unavailable. The flip side of such bold "credit easing" is the potential to reduce risk spreads and directly attenuate private sector liquidity constraints. ${ }^{9}$

Asset purchases can also be employed as a signal to the market that current policy rate expectations are too elevated. The most natural way to signal this is by buying long-term government bonds on which the central bank would expect to make a profit if its claim is correct. Unlike credit easing, the focus in this case is squarely on the benchmark riskfree yield curve, not on private sector risk premia or credit restrictions.

In sum, the effectiveness of qualitative easing depends on the central bank's ability to induce changes in market valuations or credit availability. Such effects are likely to be greatest where operations target specific distortions arising from illiquidity or market stress.

\footnotetext{
${ }^{9}$ Focusing interventions on apparently undervalued assets would also seem advantageous under a simple profit motive. However, this motive would not normally enter into the objective function of the central bank, even though it is ultimately relevant for the fiscal authority (and the taxpayers it represents).
} 


\section{Quantitative easing}

Quantitative easing refers to asset purchases financed by an expansion of the money supply. In the eyes of many observers, notably in the general press, such operations represent a step change from the unconventional policies discussed so far. This perception is arguably related to the notion that "issuing money" eventually must lead to higher nominal demand and inflation, as posited by the quantity theory. Given the empirical support for a comovement of money and nominal GDP for very long-run or extreme (i.e., hyperinflationary) fluctuations, it is indeed tempting to consider quantitative easing as an infallible tool to reflate the economy.

However, the simple equation of 'more base money, more inflation' is theoretically and empirically flawed. From a theoretical point of view, Krugman (1998) emphasizes that the determinant of longer-term inflationary trends is not just today's money supply, but the entire future path of monetary policy. This restates the now-familiar theme that market expectations of a quick reversal of monetary stimulus can choke off any effect of unconventional easing. As a technical matter, moreover, even a lasting expansion of the money supply does not automatically translate into strong stimulus. Rather, its effect on relevant broad monetary aggregates and nominal demand depends on institutional features of the monetary policy framework, including reserve requirements and the remuneration of reserves. For example, full remuneration of reserves at the policy rate allows the central bank to retain control over interbank market conditions even for high levels of excess reserves. ${ }^{10}$ As a practical implication, quantitative easing can be conducted, maintained, and unwound at a positive level of interest rates, and thus in some sense separately from conventional monetary policy.

From an empirical viewpoint, the experience from earlier banking crises also documents most clearly that the comovement between narrow money and nominal demand is by no means stable. Japan's experiment with quantitative easing during 2001-06 is particularly pertinent. While the BoJ expanded the monetary base by more than 60 percent within two years, broader monetary aggregates rose much less than proportionately,

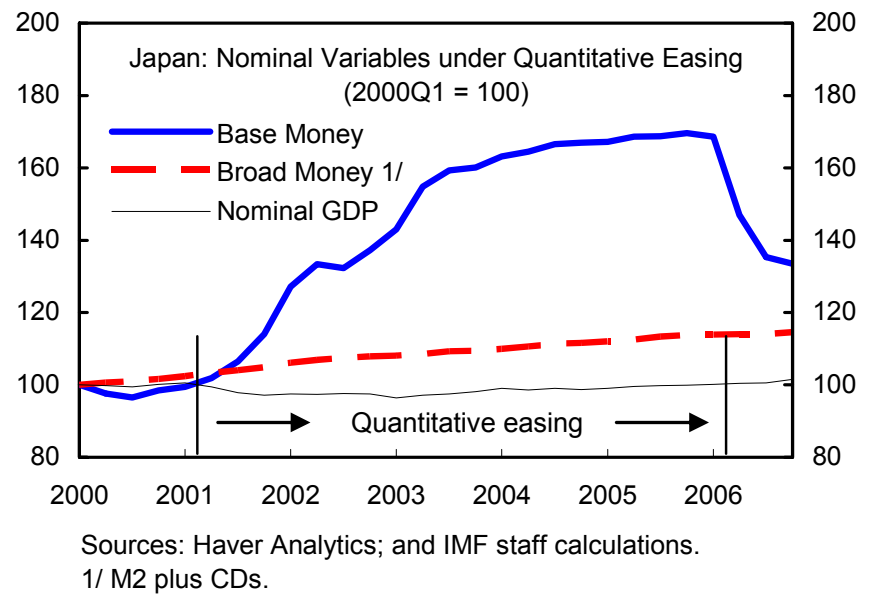
nominal demand stagnated, and inflation only turned modestly positive after several years (text chart). Matching this prima facie evidence, Ugai (2006) reports results from a range of

\footnotetext{
${ }^{10}$ The recent paper by Keister, Martin, and McAndrews (2008) discusses in greater detail this approach to "divorcing money from monetary policy."
} 
empirical studies whereby the BoJ's base money expansion had very limited direct effects, including on asset prices. It is impossible, of course, to determine exactly what would have been Japan's counterfactual experience had the BoJ not engaged in quantitative easing. Moreover, the weak financial state of Japan's banks during the period may have been an important constraining factor. This concern, however, is equally relevant under current circumstances in the global financial system. Thus the Japanese experience does little to change the view that quantitative easing is not an all-powerful tool to restart inflation.

In fact, the difference between qualitative and quantitative easing is less fundamental than might first appear. At the lower bound, quantitative easing can be thought of as combining two actions: (i) a sale of short-term government paper to finance purchases of the targeted assets; and (ii) issuance of money to buy back the short-term government paper. Operation (ii) is basically neutral as money and other safe short-term assets are perfect substitutes at the lower bound; and operation (i) is the same as under qualitative easing, except that it can now be undertaken at a larger scale, reflecting the central bank's unlimited capacity to issue money. Aside from such scale effects, the only other significant difference relates to the impact of money-financed asset purchases on the banking system. To the extent that the sellers of the targeted assets are nonbanks, quantitative easing (but not qualitative easing!) causes an expansion of bank balance sheets, as higher central bank reserve balances are matched by higher bank deposits of asset sellers. It is worth noting, however, that this is but a first-round effect, since asset sellers may also choose to pay down existing bank debt.

Taken together, these reflections cast some doubt on the potency of quantitative easing. Still, the tool should be at least as effective as qualitative easing. For one thing, the option to scale up asset purchases allows for potentially stronger effects through the same channels discussed before. In fact, its money-issuing powers enable the central bank to enforce actual asset price floors, although this strategy presents specific challenges, too (Box 1). A signal about relatively looser future policy may also be more credible if the public perceives quantitative easing as a uniquely aggressive strategy. Beyond that, it is conceivable that banks might respond to higher customer deposits and reserve balances by extending more loans. Note that this would represent a distinct liquidity channel, going beyond the standard portfolio balance effect. However, its strength is very doubtful, notably in times when bank lending is constrained by scarce capital and high credit risk more than by tight liquidity. Similarly, increased liquidity per se is unlikely to prompt additional spending by asset sellers, given that such investors should not have faced binding liquidity constraints before. ${ }^{11}$

\footnotetext{
${ }^{11}$ The text omits discussion of the famous "helicopter drop of money", i.e., a transfer to the public of newly created money balances. Although this proposal would constitute one particular form of quantitative easing, it can be decomposed into a familiar operation already covered (money-financed acquisition of a claim on the government) and an unconventional element that, however, amounts to fiscal policy (debt-financed transfer to the public). As such, whatever effects a helicopter drop might have beyond those of "pure" quantitative easing can be attributed to a fiscal operation. This conclusion carries over to fiscal stimulus measures enacted in response to (temporarily) higher seigniorage revenue. For a discussion, see Auerbach and Obstfeld (2005).
} 


\section{Box 1: Do Explicit Asset Price Targets Provide a Foolproof Solution?}

Given the commitment problem in central bank communication about future policy, one approach is to use asset purchases to directly enforce specific market prices consistent with the sought commitment. The literature has featured a few concrete proposals to this effect, focusing on long-run government bond rates, as suggested by McGough, Rudebusch, and Williams (2005) and Kuttner (2006), or the exchange rate, as proposed by Svensson (2001). Svensson's proposal, in particular, has been branded as a "foolproof" way to end deflation, namely by pegging the domestic currency at a depreciated exchange rate that the central bank stands ready to defend through whatever size of intervention is necessary.

The relationship between expectations about future policy and such price variables is easily understood from the following identities:

$$
\begin{aligned}
& i_{t, t+k}=\left(\sum_{j=0, \ldots, k-1} i_{t+j, t+j+1}\right)+\theta_{t} \\
& i_{t, t+1}^{*}-i_{t, t+1}+\varepsilon_{t}=e_{t+1}-e_{t}
\end{aligned}
$$

where $i$ denotes the domestic $(\log )$ nominal interest rate, $i^{*}$ the foreign equivalent, $e$ the $(\log )$ nominal exchange rate, and $\theta$ and $\varepsilon$ denote relevant domestic-asset risk premia. Accordingly, a lower long-run yield, $i_{t, t+k}$, and weaker current exchange rate, $e_{t}$, are equilibrium outcomes for a given $i_{t}$ and $i_{t}^{*}$ only if the central bank either succeeds in affecting market risk premia or if it convinces investors it will keep rates low for an extended period, thus generating a higher future price level that will also justify a depreciated future exchange rate.

Technically, a central bank with unlimited money-printing powers should be able to defend any chosen interest/exchange rate below current levels, explaining Svensson's confidence about the feasibility of the "foolproof" solution. Yet if investors are reluctant to trust the central bank's resolve, the above formulae suggest that a standing offer may necessitate extremely large liquidity injections. Quite probably, this may finally cause markets to "accept" the central bank's commitment to lasting monetary expansion, especially since reneging would become very costly. However, the central bank may be worried about the risk of being tested, and thus shrink from such open-ended commitments in the first place.

Beyond the general concern about losing control over the money supply, the targeting of specific asset price levels raises further technical and political problems. In the case of longterm interest rates, even if an initial yield target can be effectively defended, any anticipation of a discrete upward revision in the target will trigger massive bond sales that could effectively force the central bank to buy the entire outstanding stock of securities. As Woodford (2005) notes, the "market" price becomes a meaningless concept in this case. Pegging at a depreciated exchange rate, in turn, risks being perceived as a competitive devaluation, which might lead to retaliatory action from trading partners (including, perhaps, offsetting currency interventions). Countering this particular objection, Svensson (2001) argues that the aimed-for increase in domestic demand easily offsets any adverse terms-of-trade effect on trading partners, but the persuasiveness of this argument certainly is not assured. At least for large economies with significant roles in international trade, these political implications are likely to be significant.

In sum, it is perhaps not surprising that major central banks have not adopted explicit asset price targets in conducting their recent unconventional monetary operations. 


\section{Risks AND Mitigation STRATEgies}

Apart from the likely benefits of various unconventional operations in providing monetary stimulus, central banks will also consider the specific risks associated with such policies. This section provides a brief discussion of key risks and appropriate mitigation strategies.

\section{A. Uncertainty About the Right Dosage, Timing, and Exit}

The effects of unconventional monetary policy are, for the most part, theoretically controversial and empirically unproven. This fact compounds the usual uncertainty about the "long and variable lags" of monetary transmission. The initial challenge for policymakers consists of determining an appropriate size of the monetary impulse: erring on the side of caution could nullify any desired impact and taint the unconventional tool as ineffective from the outset, while a very aggressive stance might create destabilizingly strong effects.

The impact on inflation expectations represents a particular unknown, with clear risks of nonlinear dynamics if, for instance, agents come to perceive unconventional policy action above a certain threshold as a lasting change to the monetary regime. A worst-case scenario, perhaps triggered by poor communication, could involve a significant rise in domestic risk premia, as markets take fright from a rudderless central bank. Needless to say, this would run precisely counter to the desired effects from unconventional policy. In fact, even if investor fears caused a fall in the exchange rate, the resulting boost to demand could easily be offset by adverse confidence effects, especially when the depreciation is disorderly.

Timing the exit from unconventional policies poses additional challenges. A belated exit could obviously lead the economy directly from inflation undershooting to overshooting, increasing overall volatility and undermining trust in a given inflation target. On the other hand, Orphanides (2004) cites two compelling examples of premature policy tightening, namely by the Fed in 1937 and by the BoJ in 2000. Both decisions were reversed when the hoped-for economic revival failed to prove sustainable.

Beyond timing, the exit decision also requires careful judgment on the appropriate speed and sequencing of monetary action. In particular, policymakers need to allow for the possibility that conventional and unconventional policy elements might interact to alter the usual transmission mechanism. A standard increase in policy rates, for instance, could prove less contractionary than usual in the presence of large excess liquidity, whose rising remuneration would boost bank profits ceteris paribus just when the central bank intends to tighten. By contrast, the mere announcement of large-scale asset sales — unless already expected - could have a stronger contractionary effect than the central bank might want to generate in the early stages of a tightening cycle. This also points to a challenge for central bank communications that starts well before the exit actually occurs. In essence, policymakers have to trade off the 
need to assure markets about appropriate exit strategies against the risk of undermining the desired initial stimulus by focusing attention too much on its later withdrawal.

To be sure, risks surrounding communication, dosage, and timing are not specific to unconventional policy, but characteristic of monetary policymaking in general. And while uncertainty about the effects of unconventional tools undoubtedly complicates the policymaker's task, the key underlying challenge remains the same, i.e., a correct reading of incipient trends in the economy. Thus, policy success will to a considerable extent depend on the general skills of the monetary policymaker and the reputational capital it has built in the past. Aside from this, a key prerequisite for success is a robust framework to preserve the central bank's operational independence throughout its unconventional operations.

\section{B. Financial Risks}

By absorbing risks previously held by the private sector, the central bank may boost asset valuations and improve access to credit. However, this comes at the risk of suffering significant capital losses if the acquired assets lose value over time. This possibility is most obvious in the case of private securities, which carry credit and market risk. Yet market risk looms even in the case of longer-term government bonds, as the hoped-for economic recovery might at some point push up interest rates and cause long-term bond prices to fall. ${ }^{12}$ Although these losses would initially be book losses only, they may come to be realized once the central bank starts unwinding its earlier monetary expansion by reselling assets into the market. Capital losses, in turn, can undermine the independence of the central bank and adversely affect its capacity to keep inflation in check, as discussed by Stella (2008).

\section{Political Risks}

Even if the central bank balance sheet can weather some financial loss due to strong existing capital cushions or appropriate indemnity arrangements, there is a reputational risk related to the possible criticism of "squandering taxpayer money". Indeed, the political sensitivity of large financial exposures is precisely the reason why risky operations would normally fall into the purview of the fiscal authority, and be subject to parliamentary oversight. Undertaken by the central bank, loss-making operations could weaken political support for its independence and erode the legitimacy of its policy mandate.

Even in the absence of any financial losses, unconventional operations obviously shift outward the boundaries of monetary policy. This can push the central bank uncomfortably far into roles usually assumed by either private actors or the government. A clear example is the

\footnotetext{
${ }^{12}$ From the viewpoint of the central bank, it may be immaterial that such losses in its own balance sheet are exactly offset, at least in the case of fair value accounting, by gains accruing to the issuer, i.e., the government.
} 
intervention in private asset markets. By targeting specific private assets and not others, the central bank risks accusations of favoritism or bias, which may adversely politicize its decision-making. Buying relatively broad asset portfolios could arguably attenuate such concerns, but would also reduce the targetedness of the intervention. The quasi-fiscal nature of operations is compounded in the case of direct lending to nonbanks, when the central bank not only decides on credit allocation, but also replaces market-price transactions with direct price-setting, possibly involving implicit subsidies. ${ }^{13}$

Buying government bonds, in turn, avoids these particular risks, but exposes the central bank to a possible perception of capture by the fiscal authority. This is true especially during times of high deficits, when central bank purchases directly alleviate pressures in the government debt market. To be sure, central bank independence ultimately always rests on a supportive fiscal authority. However, large-scale operations in government bonds create a particularly fertile ground for policy conflicts, notably over the appropriate timing and scale of central bank purchases and sales. In the limit, such operations can give rise to market fears about fiscal dominance and a consequent loss of monetary policy discipline.

Government bond purchases also expose the limits to the central bank's instrument independence. Indeed, any of the central bank's operations that affect the maturity structure of outstanding public debt can be fully offset by the government's debt management operations. In some sense this possibility of mutual neutralization is inevitable: while the central bank is in exclusive control of the short-term policy rate, it cannot be in exclusive control of all other (unconventional) policy tools. This need not even be a serious concern as long as the two players have similar interests - which is likely to be the case when there is no acute trade-off between boosting growth and keeping inflation in check — or as long as the central bank retains some tool to independently tighten policies if necessary.

In sum, unconventional operations - whether private asset purchases or large-scale intervention in the government bond market - tend to heighten the proximity between fiscal and monetary policies, potentially jeopardizing the central bank's focus on price stability.

\footnotetext{
${ }^{13}$ Exchange rate intervention, in turn, poses well-known separate problems insofar as it may run counter to the perceived interests of external trading partners (see also Box 1).
} 


\section{Appropriate Risk Mitigation}

In order to keep such risks in check, avert adverse market reactions, and maximize the chances of success for unconventional policy, four elements seem of particular importance:

- Clear communication on the nature, purpose, and manageability of the operations the central bank is undertaking. Special emphasis should be given to the continued orientation of policies toward the goal of price stability.

- $\quad$ Transparent and reliable indemnity assurances from the fiscal authority to shield the central bank from capital losses it may suffer as a result of unconventional operations. Such assurances are desirable not only to preserve the operational independence of the central bank, but also to clarify and confirm the fiscal authority's ultimate accountability for risks to the taxpayer. At the same time, risks undertaken by the central bank should be appropriately limited.

- $\quad$ Maintaining the distinction between fiscal and monetary policy. Unconventional operations, notably purchases of private sector assets, are likely to involve some quasi-fiscal elements. These should be strictly circumscribed and covered by a clear mandate from the fiscal authority.

- $\quad$ Sufficient capacity to reverse the unconventional monetary stimulus. The ability to implement an exit from unconventional policies is crucial to preserve independent monetary policy. Consequently, the central bank should be equipped with at least one of the following rights: (i) to sell assets as necessary, without approval from the fiscal authority; (ii) to pay interest on bank reserves, thus ensuring control over rates even in the presence of excess liquidity. Additional means to drain excess reserves, notably the right to issue nonmonetary liabilities, further enhance the central bank's toolkit. 


\section{Unconventional Monetary Policy in the United Kingdom}

The previous sections have outlined a range of unconventional monetary policy options, including likely transmission channels and the risks associated with such policies. The second part of this paper confronts these general considerations with the concrete experience of policy implementation in recent months. Our focus is on the BoE's quantitative easing program, which is briefly described in this section. The following section provides a tentative assessment of the program's impact on economic outcomes thus far. To put the UK experience in a broader perspective, Section VIII then compares the BoE's unconventional policy steps with those taken by other advanced country central banks, evaluating the scale, scope, and risk attributes of the respective operations in light of the general discussion above.

The BoE's Monetary Policy Committee (MPC) cut Bank Rate, the rate at which the BoE remunerates reserves and provides short-term funds to banks, by a cumulative 450 basis points to 0.5 percent between October 2008 and March 2009. MPC communication suggests that this level will mark the floor for policy rates, because even lower rates are viewed as potentially counterproductive. The main reason is an institutional feature of UK retail financial markets, in which many lending products are indexed to Bank Rate. With deposit rates already close to zero, the MPC is concerned that further Bank Rate cuts would squeeze lenders' interest margins and possibly further tighten credit supply. Overnight interbank rates have recently been close to, if slightly below, the effective Bank Rate floor of 0.5 percent. This reflects the BoE's policy of remunerating all bank reserves at Bank Rate, coupled with imperfect arbitrage in the money market: since not all participants hold reserve accounts at the BoE and the BoE's deposit facility currently pays no interest, some participants have to trade with banks that hold BoE reserve accounts to obtain interest on their overnight funds.

Even before Bank Rate reached its lower bound, the BoE launched a policy of qualitative easing in February 2009. Based on an explicit authorization from the UK Treasury, the BoE set up an Asset Purchase Facility (APF) to buy selected high-quality private sector assets financed by the issuance of treasury bills. The APF's purpose, as per the Treasury's instructions, was to promote the flow of credit to the corporate sector through purchases of suitable instruments, notably commercial paper, corporate bonds, government-guaranteed bank bonds, asset-backed paper from viable securitization structures, and syndicated loans.

The setup of the APF - at the Treasury's request, and as a separate legal entity with comprehensive indemnity assurances for possible losses-indicates that these asset purchases were initially intended as sterilized "credit easing" alongside the MPC's independent conduct of monetary policy. As such, they expanded the BoE's toolkit, although management of the APF could in principle have been assigned to any other institution with adequate technical expertise. The new tool, after all, did not fall into the realm of conventional monetary policy nor interfere with it. In the event, the BoE started buying unsecured sterling corporate commercial paper, chiefly in the primary market, in mid-February. 
However, the Treasury's original authorization for the APF already specified the possibility to turn the facility into an explicit monetary policy instrument by financing purchases with base money instead of treasury bills. Following an exchange of letters between BoE and Treasury, the MPC decided on March 5 to use this option, effectively moving from qualitative easing to quantitative easing (henceforth, $\mathrm{QE}$ ). As a quantitative target, the MPC set out to buy GBP 75 billion in assets over the three months through end-May, or half the total amount authorized by the Treasury. At its policy meeting on May 7, the MPC decided to extend its monthly purchases at the same rhythm through end-July, taking the total amount of QE to GBP 125 billion, or GBP 25 billion short of the Treasury-approved limit.

Under its QE policy, the BoE continues to buy private sector assets. Indeed, in addition to unsecured commercial paper, it started buying investment-grade sterling corporate bonds on March 25. The BoE has also declared its readiness in principle to buy governmentguaranteed bank bonds and certain types of asset-backed commercial paper, although no such transactions had been made through end-June. The BoE's stated purpose in each case is to improve market functioning, reduce illiquidity spreads, and thereby catalyze new issuance and private market activity. In practice, the BoE stands ready to buy corporate paper at a known fixed spread, and corporate bonds down to an undisclosed minimum spread over riskfree rates, making the scale of its purchases a function of current market prices.

Given the limited size of the targeted private credit markets (text chart) and the recent decline in risk spreads, total private sector asset purchases amounted to only GBP 2.7 billion at endJune, no more than a fraction of the relevant Treasury-authorized maximum amount of GBP 50 billion. As this would fall significantly short of the overall QE target, the BoE at the outset secured the right to extend its APF purchases to gilts (UK government bonds). In fact, reverse auctions for conventional gilts, with targeted residual maturities between 5 and 25 years, have contributed the overwhelming share of QE-related purchases since early March. At end-June, the APF's gilt holdings amounted to GBP 99.9 billion, or more than 97 percent of its total assets (text chart). This way, the BoE is realizing its goal to inject a significant amount of liquidity into private sector portfolios in short time without assuming credit risk.

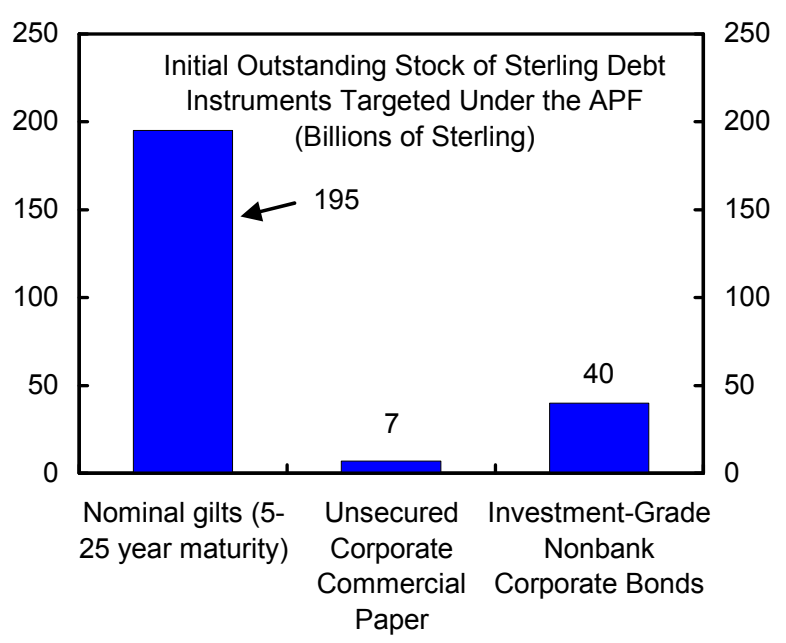

Sources: Bank of England; and Debt Management Office.

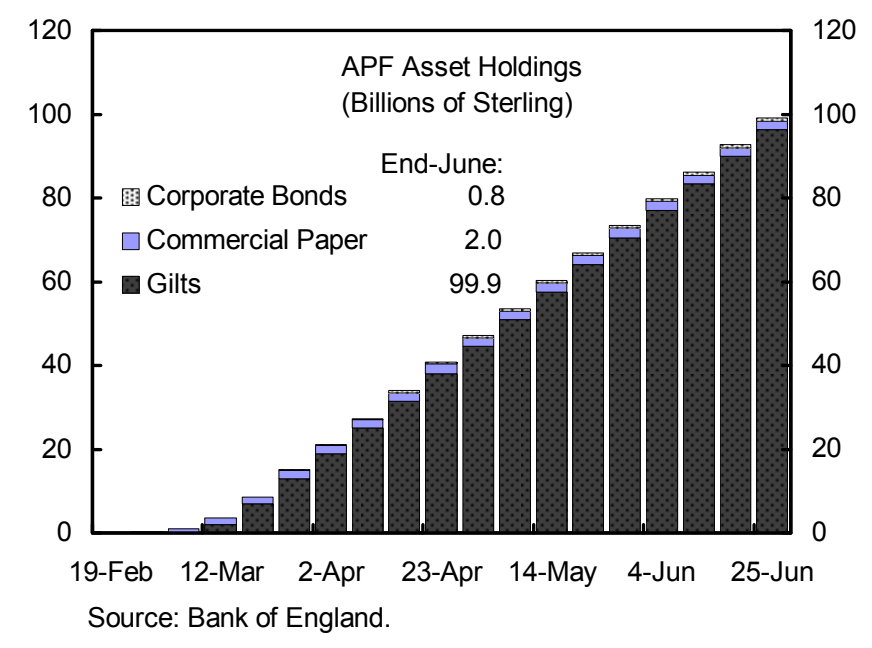


The BoE's gilt purchases are very significant also with respect to market size and trading volume in the targeted maturity segment: purchases through end-June added up to more than one-half of the initial stock outstanding and about 15 percent of the 2009Q1 trading volume. In relation to the entire stock of gilts outstanding, the BoE was holding about 15 percent at end-June. Its purchases also well exceeded the (considerable) net new issuance between March 5 and June 30.

As a result, private sector and nonresident holdings of gilts shrank over the period.

Detailed portfolio statistics indicate that all three broad investor groups-resident banks and building societies, resident private nonbanks, and nonresidents_-reduced their net holdings of gilts (text chart). Half of the net selling was accounted for by

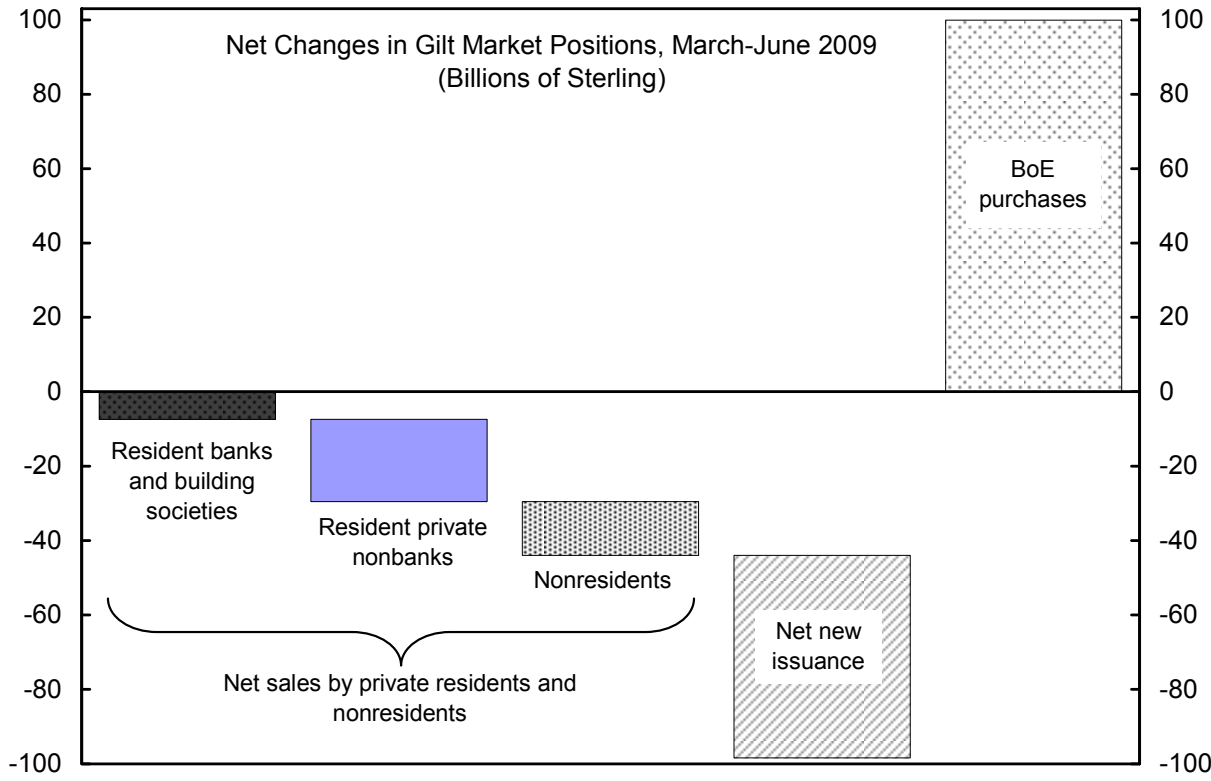
Sources: Bank of England; Debt Management Office; and IMF staff calculations. resident nonbanks. Nonresidents' share of total net sales amounted to 32.9 percent, slightly below their aggregate share in gilt holdings (36.4 percent) at end-March 2009.

With its twin-track strategy - targeted private sector asset purchases combined with largescale intervention in the gilt market - the BoE aims to provide a broad monetary stimulus through various channels. Specifically, the MPC expects its large-scale liquidity injection to trigger portfolio balance effects, lifting valuations across a wide range of assets, including the corporate debt instruments whose markets are separately targeted by the APF. Enhanced liquidity in these markets would assure potential investors that they can resell their assets with ease, thus facilitating new issuance, as well. The MPC also argues that the increased money supply could induce additional bank lending and, possibly, increase spending directly, for example, by raising inflation expectations. Together, this broadly matches the discussion of potential transmission channels in Section IV above.

That said, the MPC's initial decision on QE suggests a clear quantitative frame of reference as regards the relationships between narrow money, broad money, and nominal demand. Specifically, the liquidity injection of GBP 75 billion was calibrated so as to make up for a projected shortfall in nominal demand of about the same amount ( 5 percent of GDP), based on an assumed marginal money multiplier and money velocity of one. The significant uncertainty surrounding the transmission of QE — explicitly acknowledged by the MPC - 
would seem to caution against relying too much on any such numerical assumptions. Indeed, the MPC did not refer back to this quantitative rule of thumb when it increased the QE target to GBP 125 billion in May.
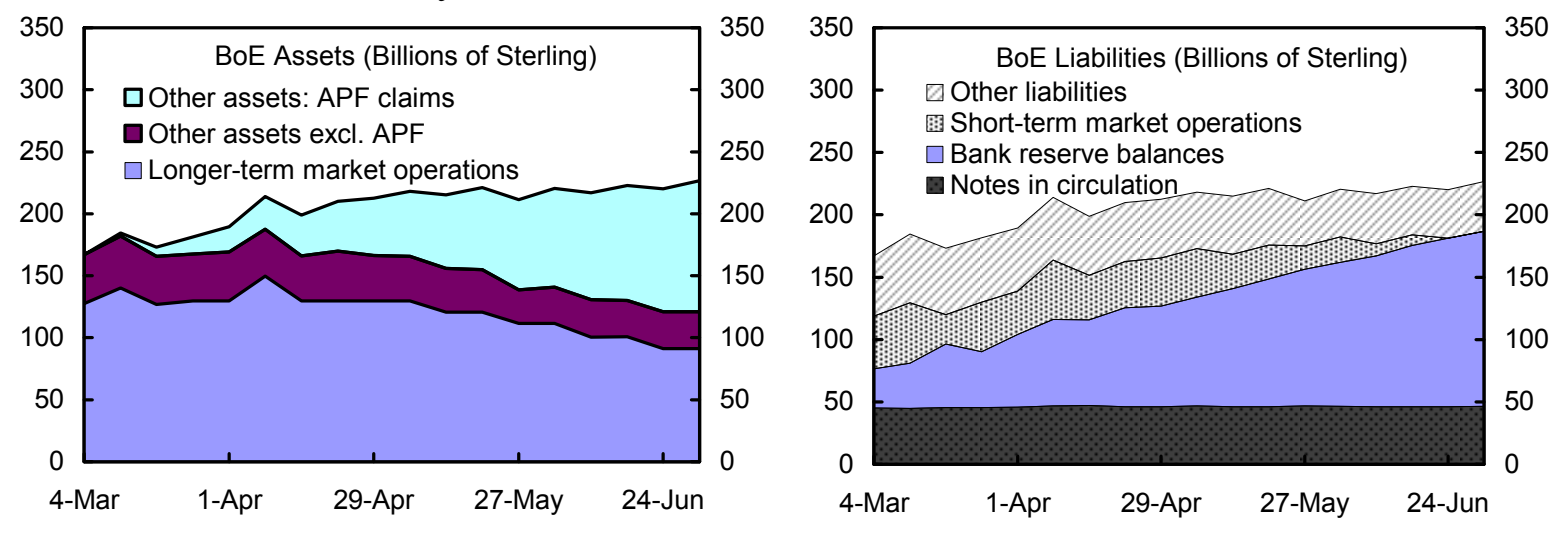

Source: Bank of England.

The effect of QE on the BoE's balance sheet has been to boost "other asset" holdings by more than GBP 100 billion ceteris paribus through end-June, matched by a quintupling of banks' reserve balances with the BoE (text charts). Indeed, banks' abundant reserve levels have simultaneously reduced the demand for the BoE's standard liquidity-providing facilities, as witnessed by the decline in outstanding longer-term reverse repo operations. In order to prevent this from offsetting the intended boost to bank reserves, the BoE has proportionately phased out its liquidity-absorbing short-term repo operations and, more recently, started injecting liquidity through short-term reverse repo operations. Looking ahead, the large remaining amount of conventional liquidity provision (some GBP 90 billion) provides one simple tool for quickly draining excess reserves once QE is set to be unwound.

Apart from its large-scale asset purchases, the BoE has made relatively limited use of the unconventional policy options discussed above. In particular, although the average maturity of reverse repo operations has increased since the beginning of the financial crisis (with most activity now in 3-month operations), the BoE has retained its usual auction format, thus letting market forces determine the price of such longer-term funding sources. ${ }^{14}$ The MPC has also maintained its policy of publishing no projections for Bank Rate. ${ }^{15}$ Nonetheless, the MPC came close to communicating its outlook for policy rates in the May 2009 Inflation Report, i.e., by indicating that it expected inflation to remain below the 2-percent target through mid-2012 on the assumption of an unchanged monetary policy stance. This provided an indirect signal to the market that the MPC did not anticipate rate increases for an extended period under its central scenario.

\footnotetext{
${ }^{14}$ The more significant change was the widening of the accepted collateral pool under the BoE's 3-month reverse repo operations, which, along with the Special Liquidity Scheme, directly addressed the shortage of standard collateral and the resulting squeeze on banks' term funding.

${ }^{15}$ Tucker (2007, pp. 11-12) discusses the political economy arguments underlying this position.
} 


\section{Gauging the Effectiveness of Unconventional Policies}

\section{A. Methodological Issues}

Even several months into the operations of the APF, evidence on the effects of BoE asset purchases on relevant economic outcomes remains tentative. This reflects not only the significant time lags between unconventional monetary operations and their likely impact on economic activity and inflation - several quarters if empirical studies on conventional monetary policy are any guide — but also the fundamental difficulty of pinpointing specific causal links. For example, there are clear signs that markets have stabilized since the launch of QE in early March, but this arguably reflects a range of important influences, including the government's banking sector support measures as well as international developments, which are hard to disentangle from the effect of the BoE's unconventional operations.

This situation exemplifies the familiar problem of missing counterfactuals: it is impossible to know, and very difficult to estimate, how the UK economy would have fared without QE but with all other relevant influences unchanged. In the absence of a full-fledged model to explain economic outcomes, one approach to deal with this problem is to use an event study. This puts the focus on developments within a narrow time interval surrounding key events, such as the launch of QE on March 5. The event-study approach appears suitable for fastmoving financial variables that are commonly thought to incorporate all public information.

However, event studies must impose a few assumptions to yield meaningful results, notably that (i) the news content of the event is not "polluted" by other important changes occurring within the same time window; (ii) the relevant event was unanticipated; and (iii) the market rapidly understands and prices in the new information. The latter assumption, in particular, is potentially restrictive in the present case, given the unusual nature of QE and the significant uncertainty about its effects. It is conceivable, for example, that investors adjust their yield expectations only gradually over an extended time period as they learn about the impact of large-scale asset purchases. More specifically, if $Q E$-related uncertainty represents itself a source of risk, yields might initially drop by less than the full expected extent, so as to induce investors to continue holding the securities until the time of the actual central bank purchase. While this particular effect would lead event studies to underestimate the impact of QE on asset prices, initial market misperceptions about QE could go in both directions.

Aside from these caveats, the event-study approach generally is not well-suited for economic variables that move more slowly than financial asset prices. On the one hand, this restriction is unfortunate, as interest is ultimately centered on such slower-moving variables as inflation and output. On the other hand, a focus on fast-moving indicators matches the discussion of plausible transmission channels above: if the BoE's QE produces no effect ceteris paribus on asset prices, lending rates, or inflation expectations, it is difficult to see how it would end up significantly affecting inflation and output. 
The difficulty in gauging the broader effects of QE can also be addressed, at least to a certain extent, by constructing simple counterfactuals for the variables of interest, for example, from cross-country or cross-period comparisons. Such simple counterfactuals will obviously be problematic in many cases, as countries and time periods differ in more than one aspect; comparator countries may themselves be influenced by spill-overs from the UK policy in question; or policy responses across countries are so highly correlated as to remove most of the variation necessary to isolate the effect of individual policies - a case in point is the nearly simultaneous adoption of (new) unconventional monetary tools by several advanced country central banks in March 2009. Nonetheless, simple counterfactuals provide a useful additional source of prima facie evidence to complement the event-study approach.

\section{B. Tentative Evidence}

The initial announcement of QE on March 5 arguably contained a significant element of surprise. While markets had anticipated the "final" cut in Bank Rate to 0.5 percent and some stepped-up asset purchases, the announced amounts of QE-GBP 75 billion over three months, with an option for an additional GBP 75 billion-clearly exceeded market expectations. This suggests that a significant part of the monetary policy news of March 5 was unanticipated. Assuming full incorporation of the news within short time and no confounding factors, the immediate market response should thus provide a lower bound for the expected impact of QE on gilt yields. In the event, the movement in the yield curve was quite striking, with medium- and long-term yields falling by between 20 and 40 basis points on the day of the announcement (text charts).
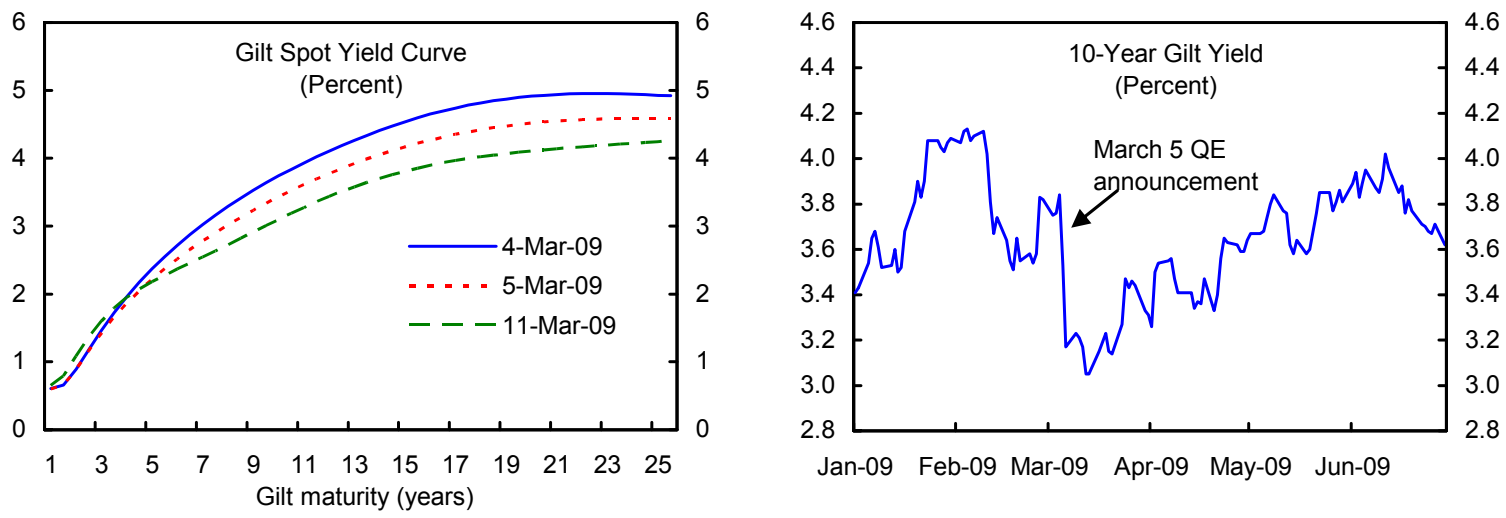

Source: Bank of England.

The downward shift in the gilt yield curve continued over the following days, pushing yields as much as 105 basis points below their March 4 levels. The effect was most concentrated in the targeted maturity segment of 5 to 25 years. Shorter maturities eased little, and longer (30- to 50-year maturities) yields dropped by "only" about 50-60 basis points. How much of these movements between, say, March 6-13, can still be attributed to the QE announcement is necessarily open to question. Given the unusually large yield moves on some of these days and the absence of obvious significant news, it seems plausible to interpret the dynamics as 
the market's gradual coming to terms with QE. However, a more narrow event-study analysis would arguably focus on yield changes on March 5 and perhaps March 6 at most.

This discussion carries over directly to the subsequent dynamics of the gilt yield curve. Indeed, after bottoming out in mid-March, nominal long-term yields started climbing again and, under significant volatility, rose back to their pre-QE levels by end-May (text chart). Did this reversal mirror the market's delayed reassessment of QE or did it reflect new information, including about the large financing needs quantified in the 2009 Budget, the higher-than-expected inflation outturns in the Spring, and the gradual stabilization of the UK financial sector? It is impossible to provide a conclusive answer, but in the spirit of a traditional event-study analysis, these subsequent market dynamics should normally not be attributed to the original news on QE. This leaves a tentative assessment of a direct impact on longer-term gilt yields on the order of 40-100 basis points. Note in this context that a separate event study for May 7, when the MPC announced the extension of QE, does not seem appropriate, as the news content of this decision is much less clear. Specifically, many investors were by then expecting an extension, even though the timing of an announcement was uncertain. Because it is impossible to determine when exactly investors started expecting more QE-related purchases - perhaps as early as at the time of the first announcement on March 5-the impact of this topping-up remains hard to establish. Logically, however, it would not lower the estimated effect on gilts from the March 5 event study.

In order to put the dynamics of gilt yields since March 4 into a broader perspective, it is instructive to compare them to bond yields in other advanced economies. Bearing in mind the caveats applying to such a foreign-country counterfactual, the comparison broadly supports the earlier event-study results. Specifically, 10-year UK gilt yields were some 10 basis points below their March 4 levels at end-June, while comparable bond yields in Germany, Switzerland, and the United States had risen by 25 to 50 basis points over the same period (text chart). The relative overperformance of gilt yields is remarkable, given that UK fiscal news

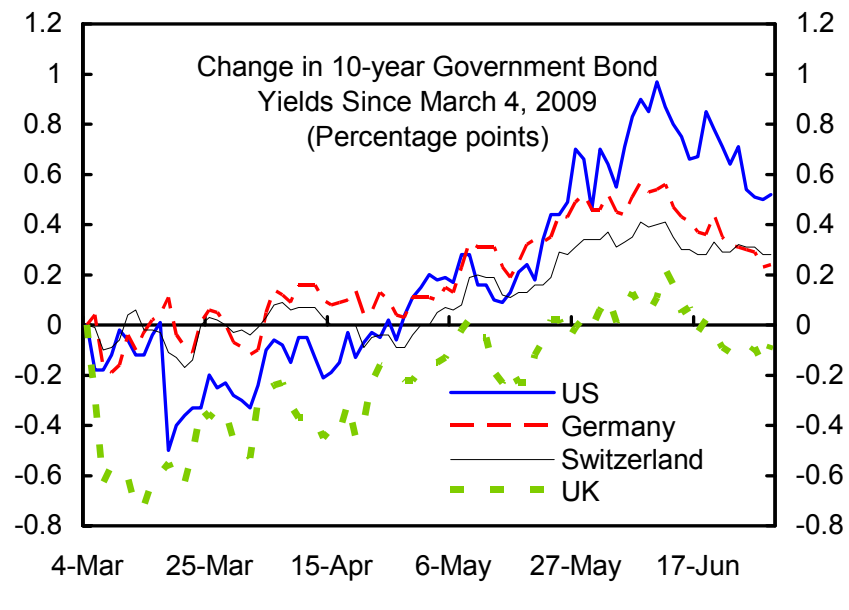

Sources: Bank of England; Haver Analytics; and IMF staff calculations.

over the period had undoubtedly been much worse than among its continental European peers, and perhaps even the United States. Moreover, U.S. bond yields would also reflect the effect of the Fed's own government bond purchase program, which was announced on March 18. Together, these considerations point to a ceteris paribus effect of QE on gilt yields of, at the very least, $35-60$ basis points. 
One important mechanism for translating such gilt yield moves into broader stimulus for the economy is a more general portfolio rebalancing. Specifically, lower yields for benchmark gilts should make it attractive for investors to shift funds into other asset classes, including corporate bonds and equities. To the extent that bank funding costs decline as well, banks might be induced to provide loans at lower interest rates, too. Together, this would generate both positive wealth effects and lower financing costs facing borrowers.

The immediate response in key asset markets on and right after March 5 provides mixed evidence on such QEinduced repricing (text chart). UK equities dropped 3 percent on March 5 and did not change significantly over the following two days. Sterling actually strengthened slightly. By contrast, developments in nongovernment bond markets reflected a significant spill-over from lower gilt yields: longer-term corporate bond yields dropped by nearly 30 basis points on March 5 and by another 30 basis points the following day. Lastly, real gilt yields also eased by about $10-20$ basis points on

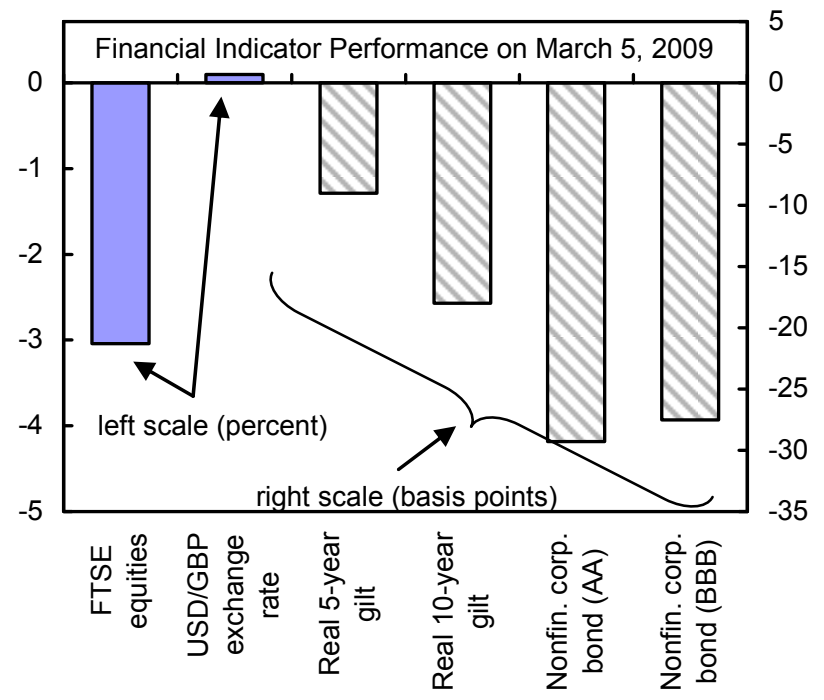

Sources: Datastream and Haver Analytics. March 5, reducing the return on what is arguably the safest long-run UK financial asset (in terms of protection against credit and inflation risk).

Considering the longer time period from March 4 through end-June, a more generalized positive performance of UK asset prices becomes apparent (text chart). Stock prices rose by

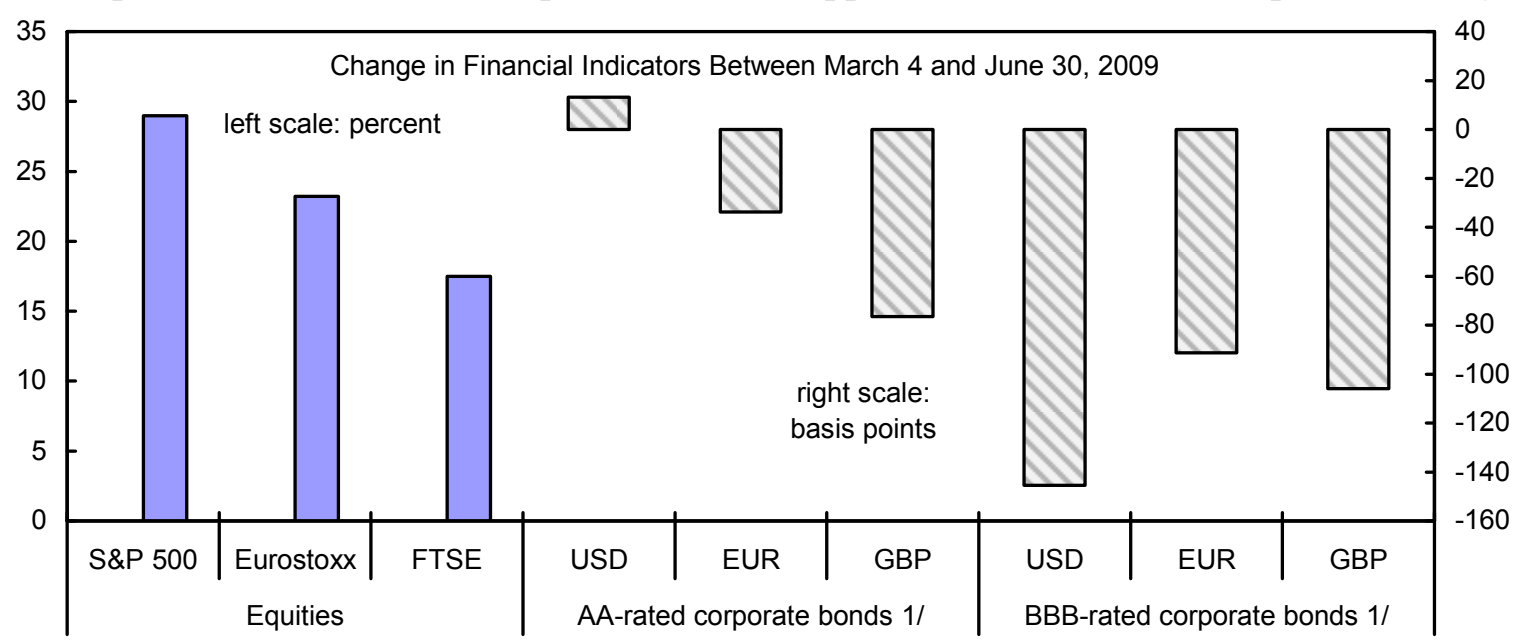

Sources: DataStream and Bloomberg.

1/ Corporate bonds with 10-15 years residual maturity, based on relevant Merrill Lynch (USD) and IBOXX (EUR and GBP) indices; includes estimated correction for index adjustment effects. 
almost 18 percent, while both highly-rated and riskier corporate bonds saw yields dropping by more than 75 basis points. These trends were coupled with a cumulative drop in real 10year gilt yields of 30 basis points, while the corresponding breakeven rates rose by about 15 basis points, pointing to some combination of lower term premia and/or a relatively more dovish future monetary policy stance. A closer look at the time path of inflation expectations implied by gilt yields reveals another interesting aspect. In fact, the 5-year spot breakeven rate, i.e., the average inflation rate over the next five years that would equate the returns of nominal and inflation-indexed gilts, rose by a significant 45 basis points, almost recovering back to 2 percent (text charts).$^{16}$ At the same time, however, 5-year forward rates, i.e., the implied rate of inflation five years from now, fell by 20 basis points, and thus remained below the level where it had been during most of 2008. Although some caution is warranted in interpreting these data, they point to a rather benign combination of higher near-term inflation expectations and well-anchored medium-term inflation expectations.
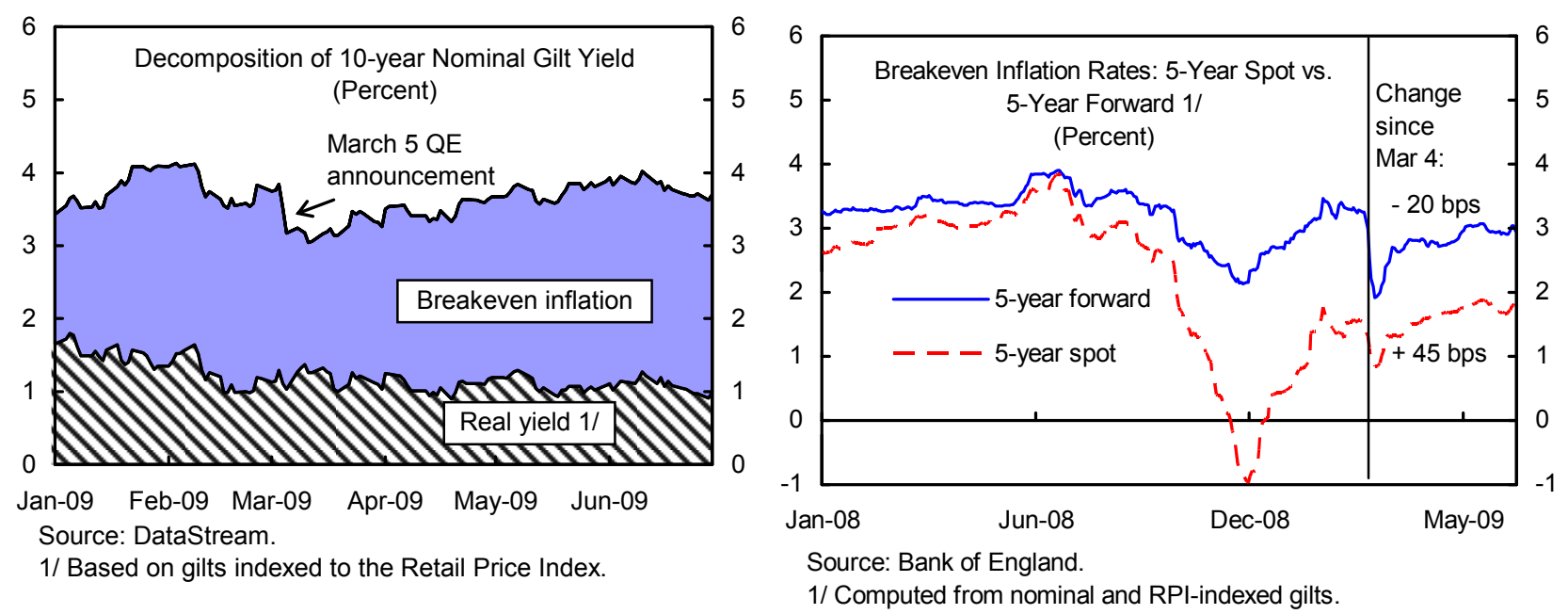

Together, these trends are perfectly consistent with the prediction of QE boosting asset prices and inflation expectations. However, a direct causal link is not obvious, as the UK experience merely fits into the global picture: the UK stock market actually underperformed somewhat its U.S. and Eurozone counterparts in local currency terms, while sterling corporate bond yields eased broadly in line with, or a little more than their peers. This leaves open the question how much QE contributed to the broad recovery of financial markets. ${ }^{17}$

\footnotetext{
${ }^{16}$ Note, however, that UK inflation-indexed gilts refer to the Retail Price Index, not the Consumer Price Index, which the official inflation target is based upon. Moreover, breakeven inflation rates are affected by variation in inflation risk premia, liquidity premia, and institutional factors that affect trading in the two markets.

${ }^{17}$ The significant share of net gilt sales by nonresidents has, in fact, prompted some public commentary alleging that much of the BoE's QE stimulus has simply spilled abroad, producing no domestic effect. However, the residency of investors contains no information a priori on how they will use the funds freed by their gilt sales. In particular, nonresidents might decide to reinvest their funds in other UK assets. And even if they move funds out of sterling, the resulting exchange rate effect would provide an alternative boost to domestic demand.
} 
Given the significant drop in corporate bond rates, including for bank issuers, it is plausible to expect some easing of bank lending rates, too. The relevant data are only available at monthly frequency and do not indicate a downward trend as yet, at least for fixed-rate products, although variable-rate products have become cheaper since February. Meanwhile, the significant rise in banking sector liquidity as a result of QE may have helped elsewhere, namely in bringing about the considerable decline in risk spreads on unsecured interbank loans (text chart). Indeed, despite a strong common trend across advanced countries, the decline has been slightly more pronounced in the sterling interbank market.

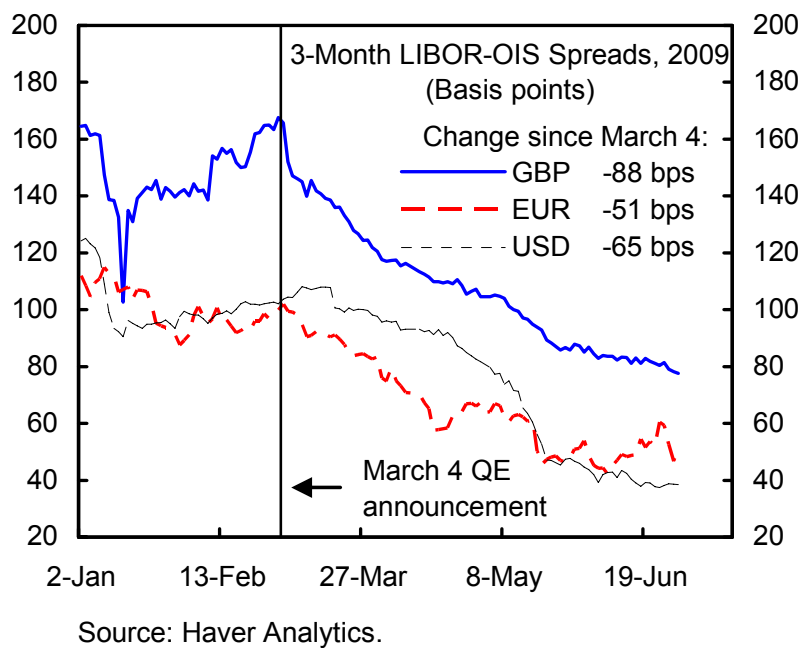

In considering the evolution of corporate bond rates, it is important to also note the potential separate impact of the BoE's corporate bond purchase program. Foreshadowed in the original March 6 market note on QE, announced on March 19, and launched on March 25, the program is designed to buy limited amounts of eligible sterling corporate bonds through auctions, as long as the spreads offered by sellers are above an undisclosed reservation level. Although the launch of the program had little discernible impact on market spreads at the outset, spreads have eased significantly over time (text chart). As a result, the volume of new bond purchases has declined recently (text chart). How much of the spread compression owes to the BoE's purchases and how much to the broader recovery in financial markets is uncertain, but the key objective of the corporate bond facility has arguably been realized.
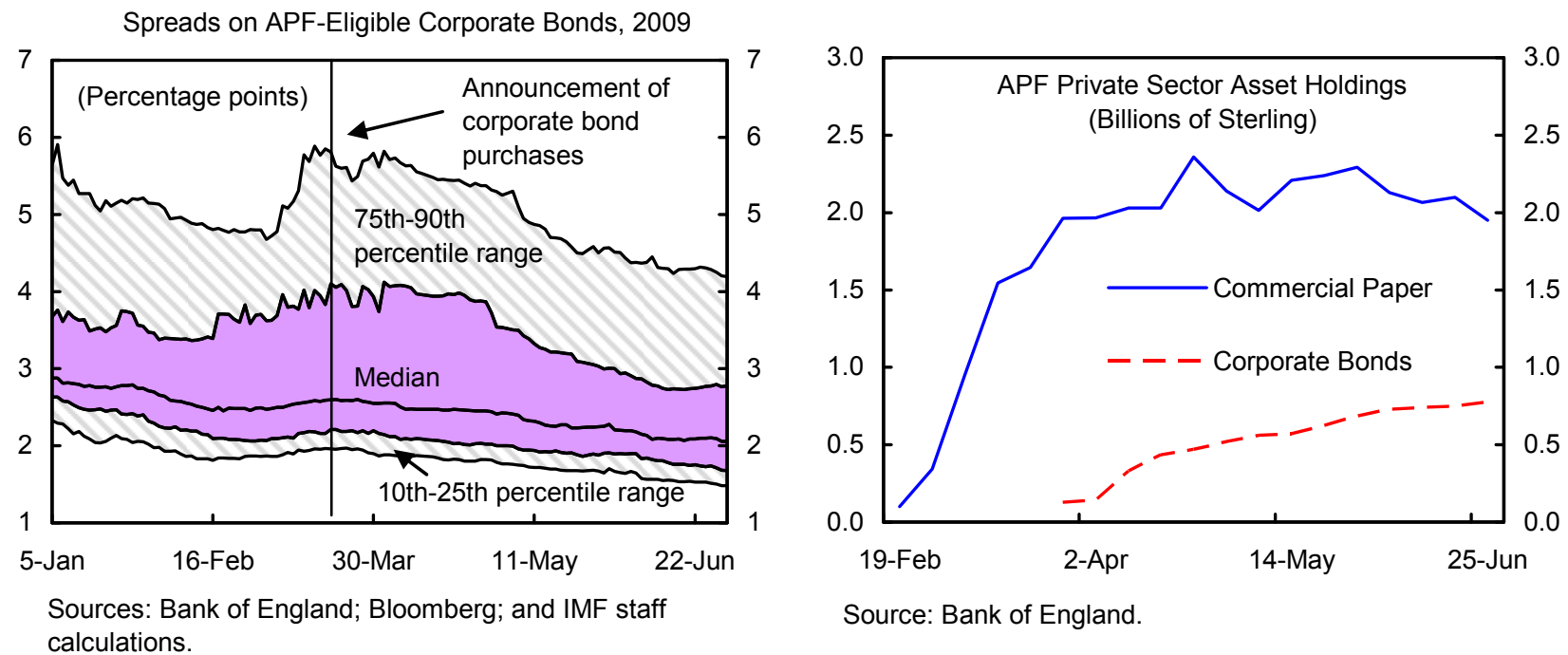

A very similar conclusion holds for the BoE's purchases of unsecured corporate commercial paper. In fact, this facility is designed to effectively set a price ceiling in the primary market, 
by buying different risk categories of commercial paper (A1, A2, A3) at publicly known spreads of 75,125 , and 300 basis points above riskfree rates. Accordingly, market rates have been kept at or below these thresholds, directly easing borrowers' access to finance. As an additional indication of catalytic effects, the BoE noted that private activity in some segments of the market had revived since the launch of the APF. That said, net issuance has actually turned negative in recent months, unlike in the corporate bond market (text chart).

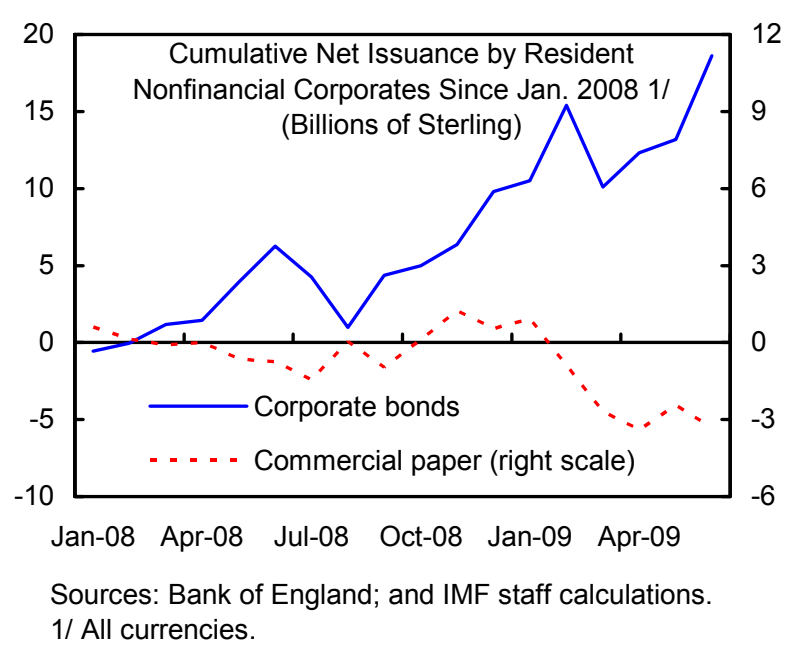

As discussed above, official BoE statements have emphasized the particular importance of broader monetary aggregates for the transmission of QE. According to the MPC's initial assumptions, the increase in base money should lead at least to a one-for-one increase in broad money. Note that while this occurs mechanically as a first-round effect of asset purchases from nonbanks, subsequent dynamics can lead to a multiplier that is either greater or even smaller than one. In particular, asset sellers could use their newly gained bank deposits to repay existing bank debt.
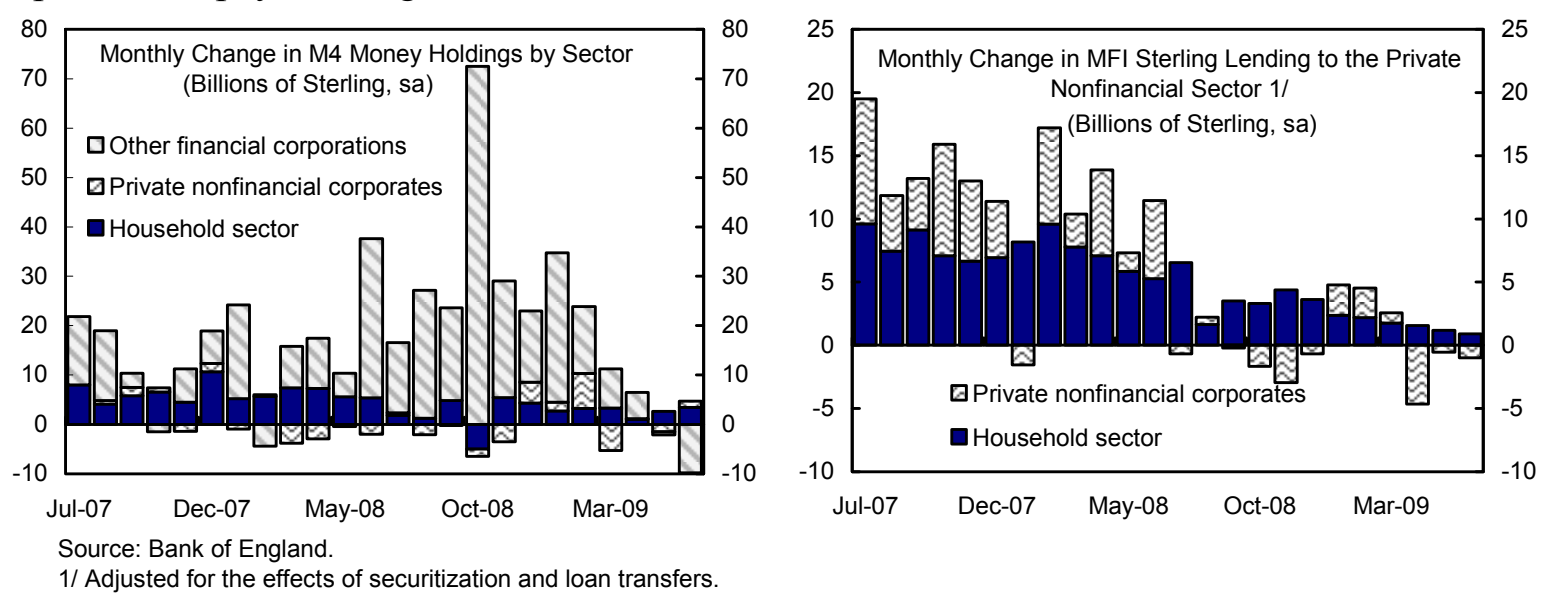

Actual developments since March point to a further deceleration of broad money growth, including for "other financial corporations", which should comprise most of the institutional investors selling assets to the BoE. ${ }^{18}$ In fact, total M4 money holdings grew by no more than a monthly GBP 2-3 billion on average during March-June, compared to a base money injection of about GBP 25 billion per month. Money holdings of the private nonfinancial corporate sector even declined over the period. This trend is matched by a continued weakening of MFI credit provision to the real sector (text charts). On this particular front, QE clearly has not yet succeeded in countering the sharp deleveraging trend in the UK economy.

\footnotetext{
${ }^{18}$ The BoE has argued, however, that these statistics may be distorted by transactions of certain intermediate institutions. Reliable data on such transactions for 2009Q2 were not yet available when this paper was written.
} 
Overall, the tentative evidence on QE effectiveness is moderately encouraging. There is some compelling evidence for a direct impact of QE-related asset purchases on gilt yields of about 40-100 basis points. Further, the BoE's asset purchases have coincided with a general recovery of asset prices, a decline in risk spreads, and a moderate increase in breakeven inflation rates. While this is consistent with the broader portfolio balance and signaling effects discussed in Section IV above, the developments have occurred against a global backdrop of financial market stabilization. This also makes it difficult to ascertain the specific impact of the BoE's private sector asset purchases, although the sought compression in spreads has essentially been achieved. By contrast, broader monetary developments remain very subdued, and it is too early to tell whether QE-induced wealth effects and lower financing costs will ultimately suffice to generate the desired increase in nominal demand.

One additional observation is in order. Counter to the standard theoretical prediction, sterling has gradually appreciated since the launch of QE in early March. This suggests that concerns about higher future price levels have been more than offset by improvements in confidence, perhaps related to the authorities' aggressive macroeconomic stimulus, including QE. The stronger exchange rate weakens the potential boost to aggregate demand. At the same time, however, it should also alleviate somewhat the fears expressed by some BoE critics that QE would necessarily lead to high inflation and currency debasement. At least so far, neither the exchange rate nor medium-term inflation expectations support such fears (text charts).
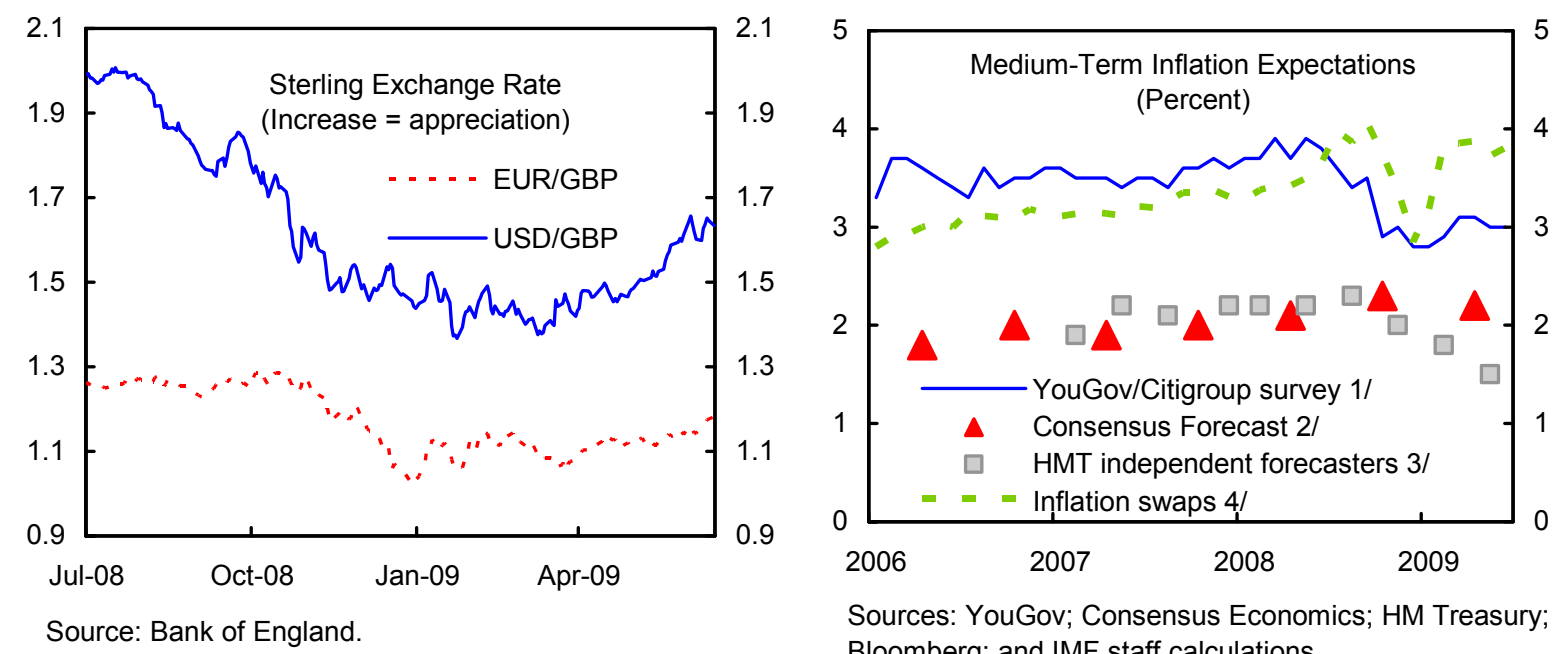

Sources: YouGov; Consensus Economics; HM Treasury; Bloomberg; and IMF staff calculations.

$1 /$ Inflation five to ten years ahead.

2/ CPI inflation in 2015.

$3 / \mathrm{CPI}$ inflation in 2011

4/ 5-year forward RPI inflation inferred from inflation swaps. 
The final paragraph is devoted to the BoE's "experiment" with implicit policy rate projections at the time of the May Inflation Report release (May 13). The Report's suggestion that policy rates would likely stay constant over the foreseeable horizon surprised markets and led to a noticeable, but decidedly short-lived drop in measured near-term policy rate expectations (text chart). Consistent with the discussion in Section IV, this may reveal the limitations of a pure communications approach to unconventional monetary policy. The experience also highlights that, far from expecting persistent monetary expansion or even a loss of monetary policy discipline, investors actually price in a more hawkish future stance even for the near term than BoE policymakers have signaled they would expect under baseline projections. This market perception again confirms that the BoE's general inflationfighting credentials have constrained, rather than been undercut by, its recent unconventional policies.

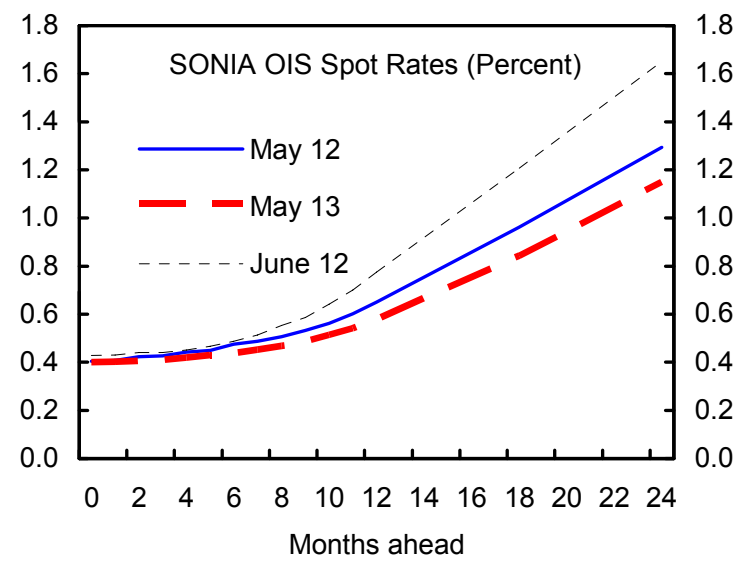

Sources: Bloomberg; and IMF staff calculations.

\section{Comparison with Other Advanced Country Central Banks}

Although highly unusual, the MPC's recent policy decisions have been taken against a backdrop of unconventional monetary policy action in many other advanced economies. Putting them into this broader context can also help crystallize the particular features of the BoE's strategy. To be sure, this section is not intended to provide a beauty contest between different central banks, nor does it attempt to provide systematic evidence on the relative effectiveness of different approaches. However, looking beyond policy decisions in the United Kingdom serves to highlight some of the general uncertainties and trade-offs associated with unconventional monetary policy.

\section{A. Type of Unconventional Operations}

\section{Communication about future policy rates}

All major central banks and a few other advanced country central banks have recently adopted at least some of the unconventional policy tools discussed in Section IV. In particular, both the Fed and the Bank of Canada $(\mathrm{BoC})$ have resorted to explicit communication about future policy rates. 
In the case of the Fed, the March 18 policy statement notes "that economic conditions are likely to warrant exceptionally low levels of the federal funds rate for an extended period." While falling short of an outright commitment to keep rates at the lower bound for a specified period, the Fed's message nonetheless aimed at guiding downward markets' expectations of future policy rates, much like the BoE's (even more implicit) communication in the context of the May 13 Inflation Report.

The BoC's policy statement on April 21, in turn, went one step further by stressing that "conditional on the inflation outlook, [the Bank] commits to hold [its] policy rate [at the effective lower bound of $1 / 4$ per cent] until the end of the second quarter of 2010." The conditional nature of the statement again limits the extent of actual commitment, and indeed an inflation targeter like the $\mathrm{BoC}$ would generally be expected to ensure an accommodative stance if inflation is well below target. That said, the specificity of the statement - no rate increase at all over the coming 14 months_-arguably did provide news to the market. Moreover, the $\mathrm{BoC}$ announced that it would seek to reinforce its commitment by rolling over some existing 1- and 3-month refinancing operations into longer-term (6- and 12-month) operations at rates between 0.25 and 0.5 percent. This effectively links communications policy to another tool discussed in Section IV, namely the extension of lending maturities at fixed rates (even though within quantitative limits). In the event, 1-year-ahead interest rate swaps eased by about 9 basis points to 0.28 percent upon the announcement. ${ }^{19}$

Overall, the experience with explicit communication about policy rates suggests some room to influence market expectations, even through relatively hedged and conditional forwardlooking statements. However, the quantitative impact appears to be limited, and forward rates have generally remained above the interest rate paths charted by policymakers. Meanwhile, central banks' reluctance to use firmer, unconditional statements is understandable, as they would not want to, and could not credibly pledge to, give up their discretion to respond to unexpected developments over the commitment horizon. Still, the BoE's principled position not to publish rate projections at all contrasts with the practice of several other central banks that routinely release such projections (central banks of New Zealand, Norway, and Sweden) or at least occasionally comment on likely future policy rates (the Fed and the BoC today, the BoJ under ZIRP ten years ago).

\footnotetext{
${ }^{19}$ As discussed above, interpreting these effects requires caution, e.g., because markets might already have anticipated some of the "news" contained in the announcement. Evaluating the effect of the Fed's March 18 communication is even less straightforward, as the same statement also announced a significant expansion of the Fed's asset purchase program. In any event, 1-year ahead interest rate swaps were little changed, but 2-yearahead swaps eased by 23 basis points to 1.46 percent on March 18, suggesting some overall effect of the Fed's announcements that day.
} 


\section{Longer-term fixed-rate refinancing operations}

The discussion above already mentioned the BoC's readiness to provide a certain amount of longer-term funding to banks at interest rates within the current policy rate interval. The European Central Bank (ECB) is the only major central bank to have taken this type of policy significantly further. Under its first-of-a-kind 12-month refinancing operation on June 24, the ECB stood ready to provide banks with unlimited collateralized loans at its current policy rate of 1 percent. Banks' demands added up to a very significant EUR 442 billion, or nearly 5 percent of Euro area GDP. Even though the transaction had been announced earlier, its execution immediately pushed interest swap rates down by about 5-10 basis points for maturities between 1 and 21 months. The significant liquidity injection is, furthermore, likely to keep interbank rates low for an extended period.

However, the ECB avoided committing to a repeat of its transaction, noting in particular that similar future operations might take place at higher interest rates. Accordingly, there is no standing commitment to keep 12-month-ahead rates capped at 1 percent. It is also worth noting that there remains some uncertainty as to whether 1 percent represents the absolute floor for ECB policy rates. For banks, borrowing funds at this rate for an extended period therefore does not necessarily represent a one-way bet. Indeed, it is striking that none of the central banks that are at their declared policy rate floor have engaged in similarly long-term and unlimited operations at that (fixed) rate. Rather, several of them have lengthened somewhat the maturity of their lending to banks (for example, up to 84 days under the Fed's Term Auction Facility), while continuing to rely on auctions to determine the relevant interest rates.

\section{Asset purchases}

The most common choice from the menu of unconventional monetary operations in recent months has been the outright buying of assets, as exemplified by the BoE's QE policy. In fact, asset purchase programs are currently also under implementation at the BoJ, ECB, Fed, and Swiss National Bank (SNB). The central banks' strategies differ, however, as to the targeted asset class and the desired impact on the money supply (text table).

Recent Unconventional Monetary Policy Operations Involving Asset Purchases

\begin{tabular}{llcc}
\hline & & \multicolumn{1}{c}{ Liability Side of the Central Bank Balance Sheet } \\
\cline { 3 - 4 } & & $\begin{array}{c}\text { No expansion of base money } \\
(=\text { "Qualitative easing") }\end{array}$ & $\begin{array}{c}\text { Expansion of base money } \\
(=\text { "Quantitative easing") }\end{array}$ \\
\cline { 3 - 4 } $\begin{array}{c}\text { Asset Side: } \\
\begin{array}{c}\text { Purchases } \\
\text { of... }\end{array}\end{array}$ & $\begin{array}{l}\text { Government bonds } \\
\text { Forivate domestic-currency assets }\end{array}$ & ECB $1 /$ & BoE; BoJ; Fed \\
\hline
\end{tabular}

1/ ECB purchases of covered bonds had not yet started at end-June and might be at least partly unsterilized. 2/ Apart from security purchases, includes direct lending to nonbanks under a range of facilities. 
Most of the central banks are following the BoE's example of unsterilized purchases. ${ }^{20} \mathrm{By}$ contrast, the ECB's purchases of covered bonds are expected to be at least partly sterilized. As discussed in Section IV, this difference is not crucial when interest rates are at the lower bound, except to the extent that money-financed purchases can be undertaken at a larger scale and with greater impact on the banking system's liquidity condition.

Regarding the targeted class of assets, the SNB stands out as the only advanced country central bank to have launched unsterilized currency interventions as an unconventional monetary policy tool. ${ }^{21}$ All of the major central banks are focusing their purchases instead on domestic-currency assets. In each case, this includes at least some type of private sector assets, testifying to the current broad support for "credit easing" operations.

\section{B. Size and Scope of Asset Purchases}

Although all major central banks have set out programs to purchase selected financial assets, there are important differences in the size, composition, and declared focus of their respective purchase programs (text table).

Outright Security Purchases by Major Central Banks

\begin{tabular}{|c|c|c|c|c|}
\hline & $\begin{array}{l}\text { U.S. Federal } \\
\text { Reserve }\end{array}$ & Bank of England & Bank of Japan & $\begin{array}{l}\text { European Central } \\
\text { Bank }\end{array}$ \\
\hline Targeted Securities & $\begin{array}{l}\text { Government bonds, } \\
\text { mortgage-backed } \\
\text { securities, agency } \\
\text { bonds, commercial } \\
\text { paper }\end{array}$ & $\begin{array}{l}\text { Government bonds, } \\
\text { corporate bonds, } \\
\text { commercial paper }\end{array}$ & $\begin{array}{l}\text { Government bonds, } \\
\text { corporate bonds, } \\
\text { commercial paper, } \\
\text { equities }\end{array}$ & Covered bonds \\
\hline \multicolumn{5}{|l|}{ Amount of net purchases announced $1 /$} \\
\hline Billions of US\$ & 2,100 & 206 & 273 & 84 \\
\hline Percent of 2008 GDP & 14.7 & 8.6 & 5.2 & 0.6 \\
\hline Percent of July 2007 base money & 255.8 & 179.3 & 29.6 & 7.2 \\
\hline \multicolumn{5}{|l|}{ Net amount purchased since Sept. 2008 2/ } \\
\hline Billions of US\$ & 859 & 168 & 33 & 0 \\
\hline Percent of 2008 GDP & 6.0 & 7.1 & 0.6 & 0.0 \\
\hline Percent of July 2007 base money & 104.7 & 146.6 & 3.6 & 0.0 \\
\hline Share of govt. bonds in purchases (percent) & $21.03 /$ & 97.3 & 92.1 & 0.0 \\
\hline
\end{tabular}

Sources: Federal Reserve Board; Bank of England; Bank of Japan; Haver Analytics; and IMF staff calculations.

1/ Based on announced maximum amounts of purchases through end-2009 for the U.S. Federal Reserve, the Bank of Japan, and the European Central Bank; and on announced target level of purchases through mid-August by the Bank of England. For U.S. Federal Reserve purchases of commercial paper, based on maximum holdings since inception of the relevant facility (CPFF). 2/ Data through June 30.

3/ Purchases of agency (Fannie Mae/Freddie Mac/Ginnie Mae) bonds and agency-guaranteed bonds account for an additional 65.1 percent of total purchases thus far.

${ }^{20}$ The term "quantitative easing" is not, however, universally used by central banks to denote their strategies. This may reflect differences in focus, as discussed in subsection B below, as well as attempts to avoid association with the BoJ's earlier QE policy, which is widely seen as less successful than initially hoped-for.

${ }^{21}$ The relatively small size of the Swiss economy may partly explain the muted response of trading partners to what might otherwise be interpreted as a "competitive devaluation" policy. Note that the Swedish central bank has also announced (sterilized) purchases of foreign exchange. Its stated goal, however, is to increase reserve levels as a precaution against possible future reserve drains on the domestic banking system. 
The Fed's program is the most ambitious in terms of volume and reach, providing for largescale purchases of private, public, and quasi-public (agency) debt securities. Indeed, these direct security purchases alone are slated to reach up to 15 percent of annual U.S. GDP. In addition, the Fed has created several liquidity facilities that provide funding support for other investors' security purchases. The most striking example is the Term Asset-Backed Securities Loan Facility (TALF), which can be scaled up to a massive US\$ 1,000 billion. The BoE's APF ranks second in terms of relative size, with announced purchases at 9 percent of GDP. The BoJ, in turn, has announced somewhat more limited asset purchases, but is the only major central bank to also buy equities (from Japanese banks). Lastly, prospective ECB asset purchases are relatively small-scale. The ECB is also the only central bank that intends to buy exclusively private-sector assets and no domestic (i.e., Eurozone) government bonds.

Considering the actual extent of security purchases thus far, the BoE's APF actually stands out as the largest program in relative terms. At about 7 percent of GDP by end-June, it exceeded not only the Fed's purchase volumes (in relation to national GDP) and the much smaller BoJ purchases. But BoE purchases were also accumulating at a much faster relative rate than during the BoJ's historical episode of QE during 2001-06, when it took more than two years for base money to expand by 7 percent of GDP (the maximum expansion was to reach about 9.5 percent of GDP in the fifth year of QE). The apparent differences in the size and speed of asset purchases arguably reflect different assessments on the need for extraordinary monetary stimulus and the effectiveness of asset purchases compared to other unconventional tools (such as the ECB's longer-term fixed-rate refinancing operations).
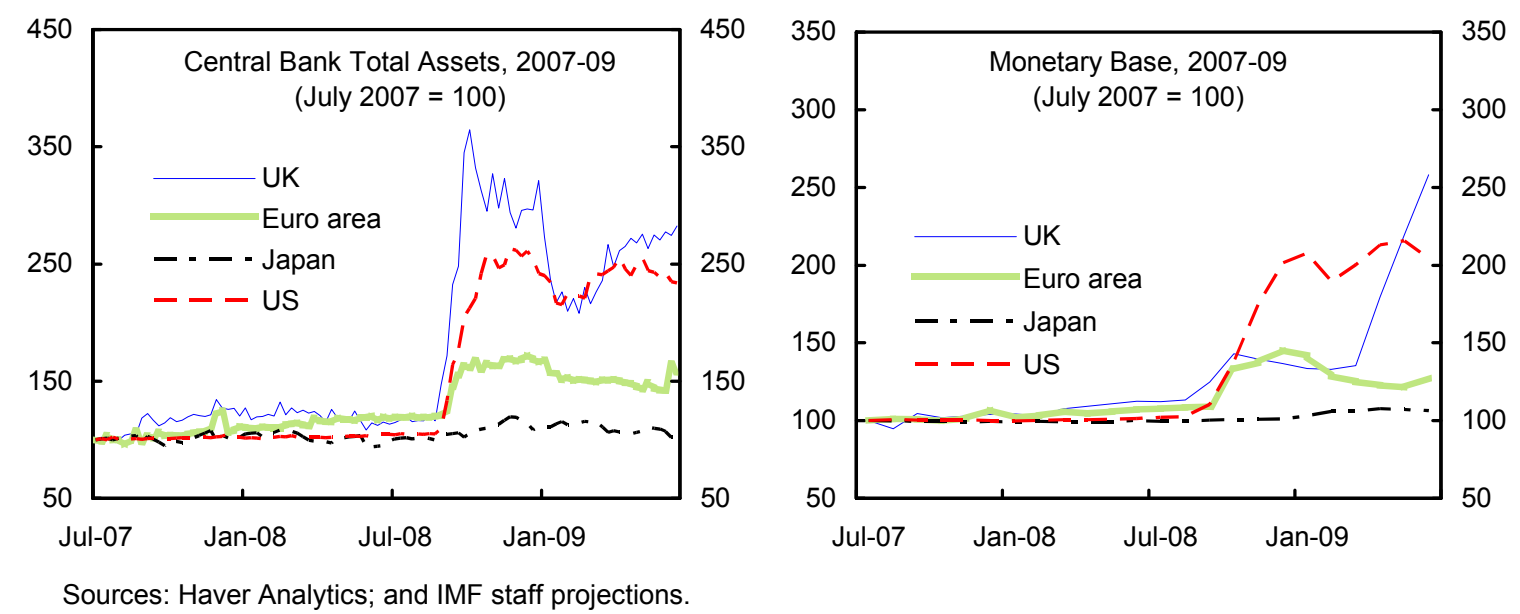

Comparing the APF with the Fed's nominally even bigger program underlines one interesting difference in approach. Specifically, the BoE has set its target in terms of an expansion of base money, giving strong prominence to the "quantitative" aspect of its aggregate purchases. As such, it has ensured, through the implementation of its purchases and accompanying repo operations, that bank reserve balances grow exactly in line with the target path (text charts). The Fed's program, by contrast, has put less emphasis on the need for higher bank reserve 
balances per se. Rather, the Fed has, from the outset, stressed its desire to affect directly conditions in the targeted asset markets. ${ }^{22}$ This approach is borne out by the less systematic evolution of U.S. base money in recent months: despite large asset purchases, base money has actually fallen slightly of late, reflecting the decreasing utilization of some liquidity facilities and relatively tepid drawings under the TALF.

To a certain extent, the differences between $\mathrm{BoE}$ and Fed policies are of a semantic nature, given the overlapping concepts of quantitative and credit easing defined above: the Fed's credit easing is implemented as QE, and the BoE's QE contains elements of credit easing. Yet the distinction arguably goes beyond semantics, pointing to somewhat different views on the relative importance of different transmission channels for unconventional monetary policy. Specifically, the Fed's approach suggests a strong emphasis on direct valuation effects in targeted asset markets. Purchases of mortgage-backed securities, for instance, are meant to directly lower banks' refinancing costs, thus supporting retail mortgage markets. Such effects also feature in the BoE's account of its unconventional policies. With respect to the dominant element of gilt purchases, however, the MPC's communication clearly emphasizes the essence of a large-scale liquidity injection per se over specific price effects.

Consistent with this strong "quantitative" emphasis, the BoE's purchase program has the lowest share of private-sector purchases among the four major central banks. At endJune, gilt purchases accounted for 97 percent of all APF holdings, compared to 92 and 21 percent in the respective purchase programs of BoJ and Fed. The ECB, in turn, buys no government bonds at all. The dominance of gilt purchases in the BoE's operations is also apparent from their size relative to the market segment. Gilt purchases through endJuly are projected to account for more than half of the original stock outstanding, while the corresponding numbers are much lower for both the Fed's and the BoJ's purchases of their respective government bonds (text chart).

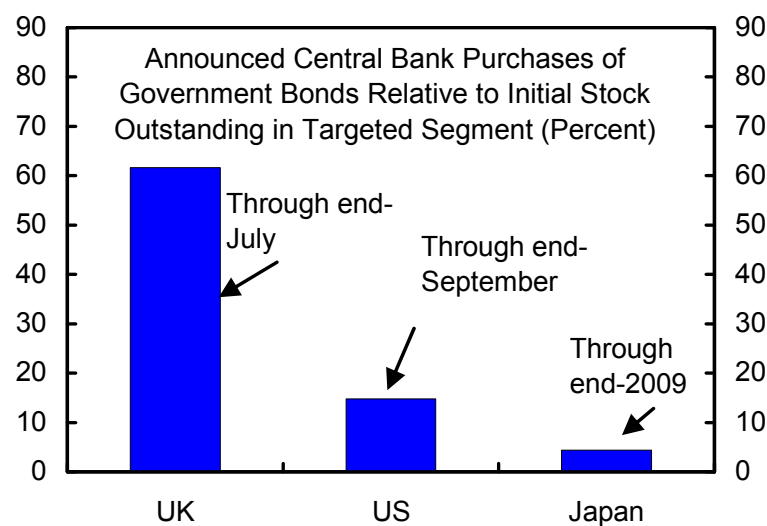

Sources: UK Debt Management Office; US Treasury; Japanese Ministry of Finance; and staff calculations. 1/ UK: Nominal gilts (excluding central government holdings) with remaining maturities of 5-25 years; US: marketable treasury notes, bonds, and TIPs with remaining maturies of 2-10 years; Japan: JGBs held outside of general government and Bank of Japan.

In making such comparisons, it is important to recognize the underlying differences in market structure and size. The dominant part of Fed asset purchases, for instance, falls on

\footnotetext{
${ }^{22}$ In fact, Fed purchases were initially launched as sterilized operations, with higher government deposits and lower treasury holdings offsetting the liquidity injection in private credit markets.
} 
agency bonds and agency-guaranteed mortgage-backed securities, which are very similar to government bonds but have no exact equivalent in the United Kingdom. Further, commercial paper markets are significantly larger in the United States, providing greater scope for marked-based funding of the corporate sector than in more bank-centered financial systems like the United Kingdom or the Euro area. The BoJ's readiness to buy equities, in turn, reflects the particular importance of equity holdings in Japanese bank balance sheets.

Similarly, the ECB's exclusive focus on covered bonds mirrors the unmatched importance of such securities for mortgage refinancing in the Eurozone. Lastly, the ECB's hesitancy to buy government bonds must be seen in light of its unique position as a supra-national central bank that has not one but sixteen fiscal authority counterparts.

Taken together, the cross-sectional variation in the scale and nature of asset purchases arguably reflects different economic circumstances, along with corresponding judgments about the relative benefits of various unconventional operations. In addition, central banks' readiness to engage in unconventional policies is circumscribed by the risk attributes of the respective operations, notably their possible impact on operational independence. The next, and final, subsection considers this issue in detail.

\section{Approaches to Risk}

Despite the large scale of its asset purchases, the BoE is pursuing a very cautious approach with respect to credit risk. This is apparent from (i) its quantitative emphasis on government bond purchases; (ii) the focus, in its private sector asset purchases, on a few selected credit markets with clear limitations for credit risk; and (iii) the design of these private asset purchases as a mere backstop, which puts the BoE into a position of marginal facilitator, rather than significant net provider of credit. Indeed, cumulative net purchases of no more than GBP 3 billion pale relative to the Treasury's initial authorization to buy private sector assets up to a maximum amount of GBP 50 billion. Even considering the limited size of nonbank credit markets in the United Kingdom, the APF arguably underexploits the scope for direct credit support to the real sector.

This observation has given rise to some public criticism, including Buiter (2009) and Barrel, Kirby, and Pillonca (2009), that the APF is not used in the most effective way. The critics see purchases as far too concentrated on the safest UK asset, i.e., gilts, thus forgoing the greater stimulative effects inherent in private asset purchases. As discussed above, this criticism views asset purchases mostly through their direct impact on asset prices and access to private credit, less so through the resulting expansion of base money per se. If private credit markets exhibit more pronounced frictions than the gilt market, as seems probable, purchases of private assets should generate greater direct valuation and liquidity effects.

Against such criticism, official BoE statements have pointed out that there are both technical and principled arguments for restraint in private credit market intervention. On the technical 
side, purchase facilities take time to set up, in order to ensure appropriate credit screening and pricing mechanisms. The BoE has also insisted that facilities ought not to be judged by the volume of purchases but by their impact on market functioning. While these arguments seem perfectly reasonable, they cannot fully explain the limited number of private credit markets in which the BoE has made purchases so far. In particular, the BoE has not yet used the Treasury's authorization to acquire syndicated loans, government-guaranteed bank bonds, and longer-term asset-backed securities. Its hesitancy in these areas thus reflects other, more fundamental considerations.

As repeatedly stated in official documents, one BoE concern is to avoid propping up markets that might not be viable in the long run. Explicit assessments of such viability have not been published, but the criterion is likely to rule out certain types of asset-backed securities. At the other end of the spectrum, the BoE is eager to avoid replacing private investors. Accordingly, it would not want to buy significant volumes in markets where private buying and selling already appears to provide sufficient liquidity and orderly price discovery. This concern appears to have argued against purchases of government-guaranteed bank bonds thus far.

Even beyond these considerations, however, the BoE has signaled a general restraint toward operations in private credit markets, citing the fundamental need to avoid reputational risks and keep monetary and fiscal policy apart. Tucker (2009), for instance, argues that "not only does exposure to reputational risk matter. Central banks should not be involved in providing facilities which ... would be likely to result in a transfer of resources to the private sector. That is the realm of fiscal policy. Central banks should stick to central banking." And King (2009) insists that "the Bank must not become the arbiter of the allocation of public credit to individual companies or sectors - such decisions are rightly and necessarily the province of government. So there is a limit to the scale of the Bank's activities in this area."

Overall, its very limited intervention in private asset markets sets the BoE's unconventional operations apart from those of other major central banks. For instance, the BoJ's outright equity purchases, even if conducted at a modest scale, undoubtedly involve greater private risk exposure than any of the BoE's facilities. The ECB's covered bond purchases, in turn, are judged to be of very low risk, but will nonetheless constitute private sector asset purchases on a much more significant scale than the BoE's. ${ }^{23}$ Lastly, under the TALF, the Fed stands ready to fund purchases of various asset-backed securities with non-recourse loans. Even with conservative haircuts and fiscal backing through TARP funds, these loans to financial investors represent an unusually risky operation for a central bank.

\footnotetext{
${ }^{23}$ Even though the ECB accepts little risk through its outright purchases, it has been argued that its comparatively more liberal collateral policy may expose it to greater risk in its regular refinancing operations.
} 
The BoE's relative conservatism is remarkable insofar as it coincides with exemplary protection against the risks arising from its asset purchases. Notably, the APF is set up as a separate legal entity under explicit, comprehensive, ex ante indemnity assurances from the Treasury, shielding the BoE from any financial risk. None of the other major central banks enjoys similarly robust protection against possible losses from unconventional operations. The Treasury's authorization for the APF provides, moreover, a detailed mandate for the BoE's asset purchases, establishing a clear legal basis for any operations outside of the bounds of normal monetary policy. The Treasury has also clarified that the BoE will not need its approval to sell APF assets. Combined with the capacity to pay interest on all bank reserves and to issue BoE sterling bills, this gives the MPC full technical control over a future "exit" from its unconventional policy.

As these considerations make clear, the BoE's cautious approach to credit risk goes well beyond addressing immediate risks to its operational independence. It appears to reflect, in particular, a general concern that significant moves outside of its usual mandate, even with explicit Treasury authorization, could ultimately come to delegitimize its authority.

Where does this leave the case for stepped-up intervention in private credit markets? A clearcut judgment is difficult to make, as there are valid arguments on both sides of the debate. In a sense, the plausibly greater effectiveness of such interventions, relative to gilt purchases, needs to be traded off against the inherent additional risk as perceived by the monetary policymaker. The robust institutional setup of the APF suggests that some further expansion of private asset purchases should be feasible without giving rise to adverse consequences. If, however, the BoE perceives a strong self-limitation as opportune, the debate should arguably shift to a different level, i.e., about the appropriate division of labor among the authorities.

Indeed, there is no absolute requirement for the central bank to be in charge of "credit easing" operations as long as they can be executed in a sterilized fashion. A key argument for using the central bank is its relevant expertise from daily operations in financial markets. Yet, nothing should stop a government to assign what it sees as desirable financial interventions to another (suitably equipped) public authority. A case in point is the recent setting-up of a corporate bond purchase fund in Norway, which will be managed by Norway's existing social security fund, Folketrygdfondet. Additional examples are the commercial paper purchases recently launched by the Development Bank of Japan, and the purchase auctions for mortgage-backed securities at the Canada Mortgage and Housing Corporation.

One additional note on risk attitudes seems in order. Specifically, the BoE's declared concerns about credit risk contrast with its apparent insouciance regarding the risks surrounding gilt purchases. It is obviously true that gilts imply no relevant credit risk to the $\mathrm{BoE}$, but their exposure to market risk is quite significant. Any sale of gilts in a future environment of higher bond rates would entail capital losses. Even if such losses are exactly balanced, in a marking-to-market sense, by corresponding gains on the part of the debtor, i.e., 
the government, the appearance of large losses from the BoE's operations could nonetheless be problematic. Even more important, large-scale gilt purchases lend themselves more readily to perceptions of fiscal dominance. The robust institutional setup of the APF provides assurances that its operations will not be subjected to fiscal policy motives. However, market perceptions of such risks can change, often for reasons beyond the control of the monetary authority, notably bad fiscal news. In that sense, its massive interventions in the gilt market accentuate the BoE's dependence on investors' continued trust in the stability of the public finances. Given the BoE's stated intent to keep monetary and fiscal policies clearly separated, it is striking that this concern does not seem to feature more prominently in its assessment of gilt purchases as an unconventional tool. Incidentally, this position differs markedly from that of the ECB, whose abstention from government bond purchases reflects concerns about conflating fiscal and monetary policies in the Euro area.

\section{CONClusion}

Unconventional monetary policy, by its nature, involves even greater-than-usual uncertainty about the economic impact of specific operations. In principle, unconventional operations can provide additional stimulus - even at the lower bound for short-term interest rateseither by signaling a relatively looser future stance of monetary policy or by directly reducing risk premia and boosting activity in financial markets. The strength of these channels is controversial, but empirical studies suggest at least modest scope for stimulative effects. The biggest obstacle to obtaining significant stimulus is, ironically, the central bank's perceived commitment to low inflation, which makes an extended monetary expansion less credible.

Against this backdrop, the BoE has been conducting a mixed strategy, combining a largescale liquidity injection into private portfolios via gilt purchases with more targeted intervention in specific private credit markets. The results from the first four months of these operations are moderately encouraging, as the BoE's asset purchases appear to have pushed yields downward ceteris paribus, while liquidity conditions in private credit markets have improved. The broad recovery in asset prices since March, along with a rebound in near-term inflation expectations, also matches the hoped-for impact of quantitative easing, although a direct causal link is difficult to establish. It remains, in any event, too early to tell whether these effects will prove strong enough to ultimately generate the desired increase in aggregate demand. Monetary policy alone also clearly cannot address all problems related to a still-fragile financial sector. QE may work, but it is not a panacea (what is, anyway?)

Reassuringly, the experience of the last few months has not vindicated some of the more alarmist voices who link QE to ineluctable currency debasement and hyperinflation. Despite a welcome recovery of near-term inflation expectations, medium-term expectations remain well-anchored, and sterling has actually strengthened since March. These developments testify to the market's continued trust in the BoE's will and capacity to deliver inflation 
outcomes in line with its 2-percent target. The robust institutional setup of the Asset Purchase Facility underpins this trust. QE clearly does not have to be a curse.

Nonetheless, there are challenges ahead, notably related to the appropriate timing, scale, and fine-tuning of the BoE's unconventional operations. On the latter aspect, effectiveness considerations argue for some further diversification of the BoE's asset purchases into temporarily dysfunctional private credit markets. In fact, such purchases are likely to have a greater impact on real sector financing conditions than gilt purchases, by directly improving market liquidity and lowering spreads. The downside is an increased exposure to credit risk, which the BoE has generally treated with great caution, including compared to other major central banks. This mirrors concerns that credit provision to private nonbanks stretches the BoE's operations well beyond standard monetary policy. The Treasury's explicit authorization and indemnity assurances for the APF should mitigate these concerns. Yet if the BoE remains wary of providing as much support for private credit markets as the government might want to see, it may actually be advisable to reconsider the current division of labor altogether. After all, private credit support is a sufficiently unconventional task to be assigned to a suitable entity outside of the central bank, as long as (i) this entity does not interfere with the BoE's control over the money supply, and (ii) the BoE retains enough instruments to achieve the inflation target even with policy rates at the lower bound.

Decisions on the overall scale and timing of further BoE asset purchases and sales also represent difficult judgment calls. They are not, however, fundamentally different from the Monetary Policy Committee's usual decision-making, insofar as they are aimed at the same objective of price stability, and guided by the same practice of carefully examining a large set of data and interpreting nascent trends. In the context of QE, this process may require even greater attention to monetary developments, asset prices, and inflation expectations. There will also be greater uncertainty about specific quantitative links. But in principle the MPC is well equipped to decide and implement the necessary steps. This includes, notably, the BoE's technical preparedness to implement an exit from QE when warranted, using a combination of higher policy rates, asset sales, and possibly other liquidity-draining operations.

Meanwhile, judicious implementation of monetary policy alone will not be enough to ensure success. Indeed, the public's trust in the operational independence of the central bank ultimately rests on the sustainability of the public finances. While this is true under any circumstances, the notion gains particular salience at a time when the central bank conducts significant purchases in the (fast-growing) government bond market. This underscores the need for fiscal policy to resolutely dispel any doubts about sustainability.

The active current debate about each of the above-mentioned aspects makes quite clear that $Q E$ is not a nonevent either. Instead, it is to be hoped, not unreasonably, that it will prove a helpful extension of the BoE's usual monetary policy toolkit — not all-powerful or entirely riskfree, but adequate to ensure price stability under the current extraordinary circumstances. 


\section{$\underline{\text { References }}$}

Andres, Javier, J. David Lopez-Salido, and Edward Nelson (2004): “Tobin's Imperfect Asset Substitution in General Equilibrium," Federal Reserve Bank of St. Louis Working Paper 2004/003-A.

Auerbach, Alan J. and Maurice Obstfeld (2005): "The Case for Open-Market Purchases in a Liquidity Trap," American Economic Review, 95(1), 110-137.

Barrel, Ray, Simon Kirby, and Vladimir Pillonca (2009): “UK Economy Forecast," National Institute of Economic and Social Research; May 6, 2009.

Bernanke, Ben and Vincent Reinhart (2004): "Conducting Monetary Policy at Very Low Short-Term Interest Rates," American Economic Review, 94(2), 85-90.

Bernanke, Ben, Vincent Reinhart, and Brian Sack (2004): "Monetary Policy Alternatives at the Zero Bound: An Empirical Assessment," Federal Reserve Board Working Paper 2004/48.

Blinder, Alan (2000): "Monetary Policy at the Zero Lower Bound: Balancing the Risks," Journal of Money, Credit and Banking, 32, No. 4, 1093-1099.

Buiter, Willem (2008): "Quantitative Easing and Qualitative Easing: A Terminological and Taxonomic Proposal," Maverecon blog December 9: http://blogs.ft.com/maverecon/2008/12/ quantitative-easing-and-qualitative-easing-a-terminological-and-taxonomic-proposal/.

Buiter, Willem (2009): “Two Yawns for the Bank of England Today," Maverecon blog March 5: http://blogs.ft.com/maverecon/2009/03/two-yawns-for-the-bank-of-england-today/.

Buiter, Willem and Nikolaos Panigirtzoglou (1999): "Liquidity Traps: How to Avoid Them and How to Escape Them," NBER Working Paper 7245.

Clouse, James, Dale Henderson, Athanasios Orphanides, David Small, and Peter Tinsley (2000): "Monetary Policy When the Nominal Short-Term Interest Rate is Zero," Finance and Economics Discussion Series, 2000-51, Board of Governors of the Federal Reserve System.

Congdon, Tim (2009): "Keep the Money Flowing to Stave Off Deflation," comment in Financial Times, July 8, 2009.

Eggertsson, G. (2006): "The Deflation Bias and Committing to Being Irresponsible," Journal of Money, Credit and Banking, 38, 283-322. 
Eggertsson, Gauti and Michael Woodford (2003): "The Zero Bound on Interest Rates and Optimal Monetary Policy," Brookings Papers on Economic Activity, 1, 139-233.

Financial Times (2009): "Fed study puts ideal US interest rate at $-5 \%$," article by Krishna Guha published April 27, 2009.

Gesell, Silvio (1934): “The Natural Economic Order,” English translation by Philip Pye, San Antonio: Free-economy Publishing Co.

Goodfriend, Marvin (2000): "Overcoming the Zero Bound on Interest Rate Policy," Journal of Money, Credit and Banking, 32, 1007-1035.

Halligan, Liam (2009): "It's Time to End the Grotesque Fiscal Bail-Outs and Grapple with Reality," comment in Telegraph, June 20, 2009.

IMF (2009): "United Kingdom—Staff Report for the 2009 Article IV Consultation," International Monetary Fund, July 16, 2009; http://www.imf.org/external/pubs/cat/ longres.cfm?sk=23104.0

Jeanne, Olivier and Lars E. O. Svensson (2007): "Credible Commitment to Optimal Escape from a Liquidity Trap: the Role of the Balance Sheet of an Independent Central Bank," American Economic Review, 97(1), 474-490.

Keister, Todd, Antoine Martin, and James McAndrews (2008): "Divorcing Money from Monetary Policy," Federal Reserve Bank of New York Economic Policy Review, 14(2).

Keynes, John Maynard (1936): "The General Theory of Employment Interest and Money," London: Macmillan.

King, Mervyn (2000): Speech to the Plymouth Chamber of Commerce and Industry's 187th Anniversary Banquet, 14 April 2000; http://www.bankofengland.co.uk/publications/ speeches/2000/speech82.htm.

King, Mervyn (2009): Treasury Committee Opening Statement Wednesday 24 June 2009; http://www.bankofengland.co.uk/publications/other/treasurycommittee/ir/tsc090624.pdf.

Krugman, Paul (1998): “It's Baaack! Japan's Slump and the Return of the Liquidity Trap," Brookings Papers on Economic Activity 1998:2, 137-187.

Kuttner, Kenneth (2006): “Can Central Banks Target Bond Prices?” NBER Working Paper 12454. 
McGough, Bruce, Glenn D. Rudebusch, and John C. Williams (2005): "Using a Long-Term Interest Rate as the Monetary Policy Instrument," Journal of Monetary Economics, 52, 855879.

Orphanides, Athanasios (2004): "Monetary Policy in Deflation: The Liquidity Trap in History and Practice," Finance and Economics Discussion Series, 2004-01, Board of Governors of the Federal Reserve System.

Orphanides, Athanasios and Volker Wieland (2000): "Efficient Monetary Policy Design Near Price Stability," Journal of the Japanese and International Economies, 14, 327-365.

Sarno, Lucio and Mark P. Taylor (2002): “The Economics of Exchange Rates," Cambridge University Press.

Stella, Peter (2008): "Central Bank Financial Strength, Policy Constraints and Inflation," IMF Working Paper 08/49.

Summers, Lawrence (1991): "Panel Discussion: Price Stability. How Should Long-term Monetary Policy Be Determined?” Journal of Money, Credit and Banking, 23, 625-631.

Svensson, Lars E.O. (2001): "The Zero Bound in an Open Economy: A Foolproof Way of Escaping from a Liquidity Trap," Monetary and Economic Studies, Institute for Monetary and Economic Studies, Bank of Japan, vol. 19 (S1), 277-312.

Tobin, James (1969): "A General Equilibrium Approach to Monetary Theory," Journal of Money, Credit and Banking, 1, 15-29.

Tucker, Paul (2007): “Central Banking and Political Economy: The Example of the UK's Monetary Policy Committee," speech at the Inflation Targeting, Central Bank Independence and Transparency Conference, Cambridge, June 15, 2007; http://www.bankofengland.co.uk/ publications/speeches/2007/speech312.pdf.

Tucker, Paul (2009): “The Repertoire of Official Sector Interventions in the Financial System: Last Resort Lending, Market-Making, and Capital," speech at the Bank of Japan's 2009 International Conference in Tokyo on 28 May 2009; http://www.bankofengland.co.uk/publications/speeches/2009/speech390.pdf.

Ugai, Hiroshi (2006): "Effects of the Quantitative Easing Policy: A Survey of Empirical Analyses," Bank of Japan Working Paper 06-E-10.

Woodford, Michael (2005): "Comment on 'Using a Long-Term Interest Rate as the Monetary Policy Instrument'," Journal of Monetary Economics, 52, 881-887. 